\title{
Anthropogenic VOCs in Abidjan, southern West Africa: from source quantification to atmospheric impacts
}

\author{
Pamela Dominutti $^{1,5}$, Sekou Keita ${ }^{2,3}$, Julien Bahino ${ }^{2,4}$, Aurélie Colomb ${ }^{1}$, Cathy Liousse ${ }^{2}$, Véronique Yoboué ${ }^{4}$, \\ Corinne Galy-Lacaux ${ }^{2}$, Eleanor Morris ${ }^{5}$, Laëtitia Bouvier ${ }^{1}$, Stéphane Sauvage ${ }^{6}$, and Agnès Borbon ${ }^{1}$ \\ ${ }^{1}$ Université Clermont Auvergne, CNRS, Laboratoire de Météorologie Physique (LaMP), 63000 Clermont-Ferrand, France \\ ${ }^{2}$ Laboratoire d'Aérologie, Université Paul Sabatier Toulouse 3, CNRS, Toulouse, France \\ ${ }^{3}$ Université Péléforo Gon Coulibaly, Korhogo, Côte d'Ivoire \\ ${ }^{4}$ Laboratoire de Physique de l'Atmosphère (LAPA), Université Felix Houphouët-Boigny, Abidjan, Côte d'Ivoire \\ ${ }^{5}$ Wolfson Atmospheric Chemistry Laboratories, Department of Chemistry, University of York, Heslington, \\ York, YO10 5DD, UK \\ ${ }^{6}$ IMT Lille Douai, Sciences de l'Atmosphère et Génie de l'Environnement (SAGE), Douai, France
}

Correspondence: Pamela Dominutti (pamela.dominutti@york.ac.uk) and Agnès Borbon (agnes.borbon@uca.fr)

Received: 3 December 2018 - Discussion started: 21 December 2018

Revised: 8 August 2019 - Accepted: 16 August 2019 - Published: 24 September 2019

\begin{abstract}
Several field campaigns were conducted in the framework of the Dynamics-Aerosol-Chemistry-Cloud Interactions in West Africa (DACCIWA) project to measure a broad range of atmospheric constituents. Here we present the analysis of an unprecedented and comprehensive dataset integrating up to 56 volatile organic compounds (VOCs) from ambient sites and emission sources. VOCs were collected on multi-sorbent tubes in the coastal city of Abidjan, Côte d'Ivoire, in winter and summer 2016 and later analysed by gas chromatography coupled with flame ionization and mass spectrometer detectors (GC-FID and GC-MS) at the laboratory.
\end{abstract}

The comparison between VOC emission source profiles and ambient profiles suggests the substantial impact of twostroke motorized two-wheel vehicles and domestic fires on the composition of Abidjan's atmosphere. However, despite high VOC concentrations near-source, moderate ambient levels were observed (by factors of 10 to 4000 lower), similar to the concentrations observed in northern mid-latitude urban areas. Besides photochemistry, the reported high wind speeds seem to be an essential factor that regulates air pollution levels in Abidjan.

Emission ratios $(\Delta \mathrm{VOC} / \Delta \mathrm{CO})$ were established based on real-world measurements achieved for a selected number of representative combustion sources. Maximum measured molar mass emissions were observed from two-wheel vehi- cles, surpassing other regional sources by 2 orders of magnitude. Local practices like waste burning also make a significant contribution to VOC emissions, higher than those from light-duty vehicles by 1.5 to 8 orders of magnitude. These sources also largely govern the VOC's atmospheric impacts in terms of $\mathrm{OH}$ reactivity, secondary organic aerosol formation (SOAP), and photochemical ozone creation potential (POCP). While the contribution of aromatics dominates the atmospheric impact, our measurements reveal the systematic presence of anthropogenic terpenoids in all residential combustion sectors. Finally, emission factors were used to retrieve and quantify VOC emissions from the main anthropogenic source sectors at the national level. Our detailed estimation of VOC emissions suggests that the road transport sector is the dominant source in Côte d'Ivoire, emitting around $1200 \mathrm{Ggyr}^{-1}$ of gas-phase VOCs. These new estimates are 100 and 160 times larger than global inventory estimations from MACCity or EDGAR (v4.3.2), respectively. Additionally, the residential sector is largely underestimated in the global emission inventories, by factors of 13 to 43. Considering only Côte d'Ivoire, these new estimates for VOCs are 3 to 6 times higher than the whole of Europe. Given the significant underestimation of VOC emissions from the transport and residential sectors in Côte d'Ivoire, there is an urgent need to build more realistic and regionspecific emission inventories for the entire West African re- 
gion. This might be true not only for VOCs, but also for all atmospheric pollutants. The lack of waste burning, wood fuel burning and charcoal burning, and fabrication representation in regional inventories also needs to be addressed, particularly in low-income areas where these types of activities are ubiquitous sources of VOC emissions.

\section{Introduction}

The West African region, located to the north of the Gulf of Guinea, is one of the most populated areas in Africa, with more than 300 million inhabitants in 2016 (United Nations, Department of Economic and Social Affairs, Population Division, 2017). The population has increased by a factor of 5 since 1950, making West Africa the fastest growing region in the world. Furthermore, future projections indicate population densities in developing countries will continue to increase. The impact in Africa will be particularly high, with projections indicating that the population of the continent could represent $40 \%$ of the world's population by 2100 (United Nations, Department of Economic and Social Affairs, Population Division, 2017). The unplanned explosive growth of urban centres in the region is a significant issue, with water access, air pollution, health problems, and unregulated emissions being identified as major concerns.

These emissions can produce diverse effects on atmospheric chemistry which are enhanced by severe photochemical conditions and dynamic atmospheric interactions. The atmospheric composition over West Africa is affected by air masses transported from remote sources, i.e. aerosol dust from the Sahara, biomass burning plumes, and local urban pollution (Knippertz et al., 2017; Mari et al., 2011). Observations performed during the AMMA (African Monsoon Multidisciplinary Analysis, West Africa, 2005-2006) campaign showed that air quality issues are predominantly related to traffic and combustion emissions (Mari et al., 2011). Residential emissions in southern West Africa (SWA) are attributed to charcoal and wood burning as they are primary sources of domestic energy, widely used for cooking and heating activities. Regional biomass burning is a significant source of carbonaceous aerosols and volatile organic compounds (VOCs) that can have effects on public health and climate through the formation of secondary pollutants (Gilman et al., 2015; Knippertz et al., 2015b; Sommers et al., 2014).

Additionally, in most of the southern West African cities, traffic emissions are major sources of air pollution (Assamoi and Liousse, 2010). The road transport sector is largely disorganized due to the underdevelopment of road networks and to the absence of a regulation policy for public transportation (Assamoi and Liousse, 2010). As a result, two-wheel vehicles are widely used in the cities for short-distance travel, replacing public transport. Furthermore, the vehicle fleet has increased in the last year, which is characterized in most cities by a large number of old vehicles (Keita et al., 2018). Over the next few years, African emissions from the combustion of fossil fuels, biofuels, and refuse are expected to increase considerably and could represent about $50 \%$ of the global emissions of organic carbon (Knippertz et al., 2017; Liousse et al., 2014). However, emission estimates are uncertain, and detailed emission inventories are still required for a better estimation of their impacts on climate change and health over this highly sensitive region (Knippertz et al., 2017).

VOCs include a large number of species which can affect air quality by producing secondary pollutants such as ozone and secondary organic aerosols (Seinfeld and Pandis, 2006). Given the reactive nature of VOCs (Atkinson and Arey, 2003), VOC emissions need to be disaggregated by species or species groups for a better representation of their chemical features and to access their impacts on the secondary formation processes. As VOCs are significant pollutants present in urban atmospheres, in situ VOC observations are necessary to directly assess exposure and to improve the prediction of secondary product formation.

Several field campaigns have been conducted in the last 20 years all over the world with the purpose of characterizing VOC species to better understand their emission sources and fate (Bechara et al., 2010; Bon et al., 2011; Borbon et al., 2013; Brito et al., 2015; Dominutti et al., 2016; Kumar et al., 2018; Salameh et al., 2015; Wang et al., 2014; Warneke et al., 2007). In particular, VOC field observations have been intensely used as constraints for the development of reliable emission inventories (Borbon et al., 2013; Boynard et al., 2014; Gaimoz et al., 2011; Niedojadlo et al., 2007; Salameh et al., 2016b). Some of these studies pointed out significant discrepancies between inventory estimations and emission ratios derived from ambient measurements, implying some limitations in the accurate modelling of VOC impacts. For northern mid-latitude cities, discrepancies up to a factor of 10 for VOC emissions have been observed (Borbon et al., 2013; Boynard et al., 2014). Such discrepancies are expected to be even more substantial in places of the developing world with high anthropogenic pressures like Africa and South America (Huang et al., 2017). For Africa in particular, the emission inventories frequently used are those developed for global scales due to the lack of observations, which involve numerous uncertainties (Keita et al., 2018; Liousse et al., 2014). While global emission inventories commonly estimate the total mass of speciated VOCs, they fail in reproducing the spatial and temporal variability of VOC emission speciation. Indeed, the emission composition can change depending on the emission source, fuel quality, combustion technologies, and main regional practices (Huang et al., 2017). The use of activity data and emission factors derived from local measurements of region-specific sources may help to reduce the uncertainties in those emission inventories. A recent study calculated the emission factors (EFs) of different compounds and activities in southern West Africa (Keita et al., 2018). A 
comparison of the emissions calculated from the EFs with those observed from the EDGARv4.3.2 (Huang et al., 2017) inventory showed a marked discrepancy (factor of 50 difference) for 15 VOC species ( 3 alkanes, 8 aromatics, isoprene, and 3 monoterpenes) in Côte d'Ivoire. That study emphasized the importance of considering African anthropogenic emissions at regional scales. Due to the scarcity of suitable data, the uncertainties in the observations cannot currently be assessed and more detailed studies are required to quantify these uncertainties. Characterization and quantification of the emissions are crucial for improving our understanding of the contributions of anthropogenic and natural sources to the atmospheric composition over southern West Africa and for assessing their impact on public health and air quality conditions.

Several intensive field campaigns in the framework of the Dynamics-Aerosol-Chemistry-Cloud-Interactions in West Africa (DACCIWA) project were conducted in 2015 and 2016 (Knippertz et al., 2015a). Here, we present the results obtained from the VOC field campaigns at different sites, including ambient and near-source measurements, in one of the major southern West African cities: Abidjan in Côte d'Ivoire. Abidjan is the economic capital of Côte d'Ivoire, with a population of 6.5 million (in 2016), representing more than $20 \%$ of the population of the country (United Nations, Department of Economic and Social Affairs, Population Division, 2017). Along with autonomous districts, Abidjan encompasses an area of $2119 \mathrm{~km}^{2}$ and is distinguished by remarkable industrialization and urbanization. In summer, West Africa is influenced by a monsoon phenomenon which is mainly driven by the surface pressure contrast between the relatively cold waters of the tropical Atlantic Ocean and the Saharan heat low (Knippertz et al., 2017). This seasonal circulation is characterized the wet (summer) and dry (winter) periods in the region. During the dry season (November to February), most of the region is dominated by dry north-easterly winds from the Sahara and the precipitation is confined to the coast, where the sea-breeze circulation provides humid air and produces nearsurface convergence. Then, the monsoon starts its development and south-westerly moist winds begin to enter deeper into the continent, producing more clouds and precipitation between July and August. The strong pressure and temperature gradients between the Atlantic Ocean and the Sahara drive the strong monsoon flow northward along with southwesterlies, reaching higher latitudes up to $20^{\circ} \mathrm{N}$ (Knippertz et al., 2015b).

Speciated VOCs were collected during DACCIWA using sorbent tubes and then analysed and quantified at the laboratory applying different gas chromatography techniques. These data provide the first constraints for the construction of a regional emission inventory and for understanding the role of anthropogenic VOC emissions in regional atmospheric chemistry.
This work aims to establish and analyse the spatial distribution of VOC concentrations and VOC-speciated profiles of primary anthropogenic sources in Abidjan by performing sampling under real conditions. These sources include traditional and region-specific ones, such as road transportation (gasoline and diesel emissions from different vehicles), charcoal fabrication, and burning emissions from domestic cooking fires, landfill waste, and hardwood fuel. This new dataset provides substantial information enabling the quantification of VOC emissions for several sources in Côte d'Ivoire. These source profiles are analysed and contrasted with those provided by global emission inventories. Finally, the impact on air quality due to the use of region-specific sources is assessed in terms of reactivity and secondary pollutant formation.

\section{Materials and methods}

As part of the DACCIWA project, intensive field campaigns were performed in 2015 and 2016, focusing for the first time on the most populated southern coastal region of West Africa. The DACCIWA campaign had an emphasis on atmospheric composition, including air pollution, health impacts, and cloud-aerosol interactions (Knippertz et al., 2015a). Here we present new results from intensive ambient measurements in Abidjan and an extended VOC speciation from source emission measurements. These results are part of the activities developed under the workpackage 2 (WP2) Air Pollution and Health, which aims to link and quantify emission sources, air pollution, and related health impacts over different urban sources in West Africa (Knippertz et al., 2015a).

\subsection{Sampling}

The field campaigns were conducted in Abidjan, Côte d'Ivoire, during summer and winter according to the strategic directions of the DACCIWA WP2. Two types of cartridges were deployed for VOC measurements: single-sorbent cartridges made of Tenax TA $60-80$ mesh $(250 \mathrm{mg})$ or multisorbent cartridges made of Carbopack B (200 mg) and Carbopack C (200 mg (carbotrap 202) purchased from Perkin Elmer). The combination of different sorbent materials allowed the sampling of 10 aromatics $\left(\mathrm{C}_{6}-\mathrm{C}_{9}\right), 22$ n-alkanes $\left(\mathrm{C}_{5}-\mathrm{C}_{16}\right), 10$ monoterpenes, 7 aldehydes, isoprene, and other oxygenated compounds. All compounds are reported in Table S1 in the Supplement. Before the sampling, cartridges were conditioned by flowing purified nitrogen, at a rate of $100 \mathrm{~mL} \mathrm{~min}^{-1}$ for $5 \mathrm{~h}$ at $320^{\circ} \mathrm{C}$.

Firstly, ambient VOCs were collected to analyse their spatial distribution in Abidjan. Ambient measurements were performed at nine sites, which are shown in Fig. 1. The distribution of the sampling locations was selected according to the primary source locations. They include urban background sites and areas impacted by residential, road trans- 
port, domestic fires, waste burning, and industrial activities. The characteristics and geographical location of each site are reported in Table 2. The ambient campaigns were conducted during the dry season (February 2016). Samples were collected every $2 \mathrm{~d}$ at different times of the day (from 06:00 to 20:00 LT) by using a manual pump (Accuro 2000, Dräger) at a $100 \mathrm{sccm}$ (standard cubic centimetres per minute) flow rate. One single sorbent tube was exposed six times at each sampling location. In total, $3.6 \mathrm{~L}$ of air was collected at each site for a single $600 \mathrm{~mL}$ volume each time. Details on the sampling strategy are reported in Table S3.

Secondly, direct source emission measurements were performed to obtain VOC emission profiles from the main anthropogenic sources in Abidjan. The sources include traditional ones like road transportation, and southern West African specific ones such as domestic waste burning, charcoal fabrication, charcoal burning, as well as wood fuel burning (Table 1). Despite part of these measurements for a limited number of VOCs (15 species, including 3 alkanes, 8 aromatics, 3 terpenes, and isoprene) and particles being discussed somewhere (Keita et al., 2018), we improve the VOC database extended to $56 \mathrm{VOC}$ species measured in the following source emissions.

- For road transportation, analysis of different vehicle exhaust measurements was carried out. Samples integrate five road transportation sub-categories: heavyduty diesel vehicles (HDDV, trucks, and buses - three samples on Tenax and three samples on Carbopack tubes), light-duty diesel vehicles (LDDV, diesel cars, two samples on Tenax tubes), light-duty gasoline vehicles (LDGV, gasoline cars, two samples on Tenax tubes), two-wheel two-stroke (TW2T, three samples on Tenax and three samples on Carbopack tubes), and twowheel four-stroke (TW4T, three samples on Tenax and three samples on Carbopack tubes) vehicles. Differences in fuel type (gasoline and diesel) and the fleet age have been considered. In African countries, two-wheel vehicles (two-stroke or four-stroke engines) frequently use a mixture of oil and gasoline derived from smuggling, which is characterized by high pollutant emissions (Assamoi and Liousse, 2010).

- Regarding domestic waste burning (WB), samples were obtained (five samples on Tenax tubes) at the official domestic landfill site located to the east of Abidjan (AD, Fig. 1 and Table 2). The sampling was performed inside the waste burning plume to integrate the different combustion processes involved.

- Charcoal burning $(\mathrm{CH})$ and wood fuel burning $(\mathrm{FW})$ are common cooking and heating practices in African urban areas. Wood fuel burning emissions were obtained by measuring the fire plume of tropical African hardwood, specifically Hevea (Hevea brasiliensis). Wood and charcoal were burned in two types of stoves traditionally used in the southern West African region for cooking, which are made of metal and baked earth. The measurements included all the combustion phases (Keita et al., 2018) (four samples on Tenax and three samples on Carbopack tubes).

- The charcoal making (CHM) profile was obtained by measuring emissions from traditional kilns that use different types of dense wood. The kiln was covered with a layer of leaves and another one of soil of about $10 \mathrm{~cm}$ thickness. The smoke was sampled through holes made in the CHM kiln, which are located in the horizontal plane and provide the air circulation for the pyrolysis propagation (Keita et al., 2018) (two samples, one on Tenax and one on Carbopack tubes).

All samples were obtained in the emission plume at around $1-1.5 \mathrm{~m}$ from the source, except for vehicles where samples were taken at the tailpipe outlet while the vehicle's engine was idling. Carbon monoxide ( $\mathrm{CO}$ ) and carbon dioxide $\left(\mathrm{CO}_{2}\right)$ measurements were also performed on the emission sources together with the VOC measurements. For this, the QTRAK-7575 sensor (TSI, Keita et al., 2018) was used to measure real-time $\mathrm{CO}_{2}$ and $\mathrm{CO}$ gas concentrations. $\mathrm{CO}$ is measured by using an electrochemical sensor with a sensitivity of 0 to $500 \mathrm{ppm}$ with $\pm 3 \%$ accuracy. $\mathrm{CO}_{2}$ concentrations are obtained by using a non-dispersive infrared detector with a sensitivity of 0 to $5000 \mathrm{ppm}$ with an accuracy of $\pm 3 \%$. The instrument was calibrated in the laboratory prior to each emission measurement. These concentrations were used for the estimation of EF values from different samples, which were later averaged for every source category. Details on the sampling strategy at emission are reported in Table S4.

\subsection{Analytical instrumentation}

Duplicate measurements were performed and analysed in two different laboratories to investigate the reproducibility of analytical techniques and to acquire a wider range of VOC species. The analysis of the Tenax TA tubes was performed at the Laboratoire de Météorologie Physique (LaMP, ClermontFerrand, France) using a gas chromatograph mass spectrometer system (GC/MS, Turbomass Clarus 600, Perkin Elmer ${ }^{\circledR}$ ) coupled to automatic thermal desorption (Turbomatrix ATD). Each tube was desorbed at $270{ }^{\circ} \mathrm{C}$ for $15 \mathrm{~min}$ at a flow rate of $40 \mathrm{~mL} \mathrm{~min}^{-1}$ and pre-concentrated on a second trap at $-30^{\circ} \mathrm{C}$ containing Tenax TA. After the cryofocusing, the trap was rapidly heated to $300^{\circ} \mathrm{C}\left(40^{\circ} \mathrm{C} \mathrm{s}^{-1}\right)$ and the target compounds were flushed into the GC. Due to the high loads in some samples, inlet and outlet splits of 5 and $2 \mathrm{~mL} \mathrm{~min}^{-1}$ were set up, respectively. The analytical column was a PE5 MS (5\% phenyl - $95 \%$ PDMS, $60 \mathrm{~m} \times 0.25 \mathrm{~mm} \times 0.25 \mu \mathrm{m})$ capillary column (Perkin Elmer) and a temperature ramp was applied to guarantee the VOC separation $\left(35^{\circ} \mathrm{C}\right.$ for $5 \mathrm{~min}$, heating at $8^{\circ} \mathrm{C} \mathrm{min}^{-1}$ to $250^{\circ} \mathrm{C}$, hold for $2 \mathrm{~min}$ ). The mass spectrometer was operated in a total ion current (TIC) from 


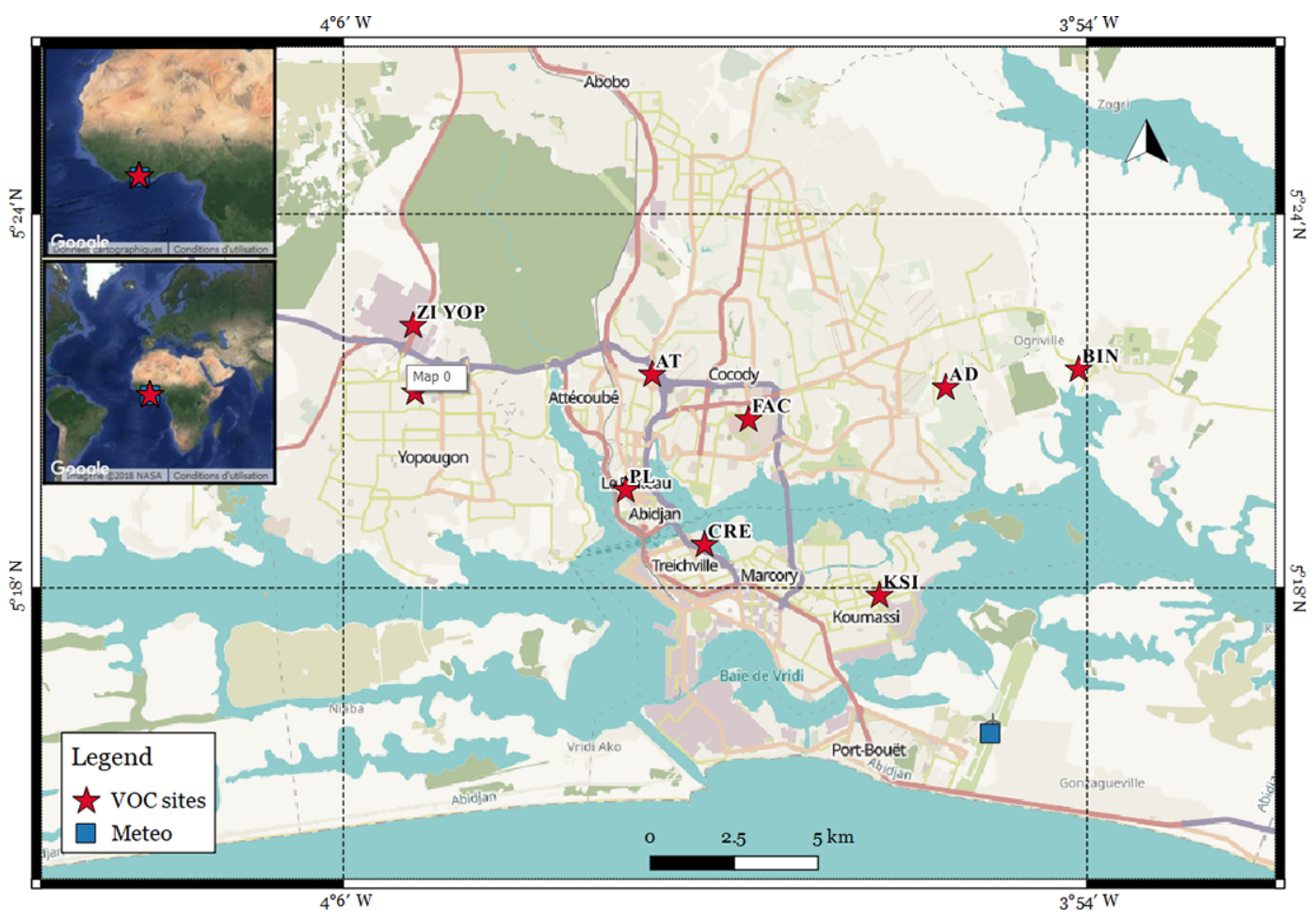

Figure 1. Geographical location of Abidjan, Côte d'Ivoire, and spatial distribution of ambient VOC measurements. Red stars indicate the VOC measurement sites and the blue square represents the meteorology site. More information about the ambient site is detailed in Table 2. Map: (C) OpenStreetMap contributors (OpenStreetMap contributors, 2015).

35 to $350 \mathrm{~m} / \mathrm{z}$ amu. Chromatography parameters were optimized to enable good separation of 15 identified compounds by a complete run of 34 min on each cartridge. Calibration was performed by analysing conditioned cartridges doped with known masses of each compound, present in certified standard low-ppb gaseous standard, purchased from the National Physical Laboratory (NPL, UK; $4 \pm 0.8 \mathrm{ppb}$ ). That method provided the separation and identification of $16 \mathrm{com}$ pounds, from $\mathrm{C}_{5}$ to $\mathrm{C}_{10}$ VOCs, including 8 aromatics, 3 monoterpenes, 4 alkanes, and isoprene. The limit of detection lies between $1.10 \mathrm{ppt}$ (1,2,3-trimethylbenzene) and $22.6 \mathrm{ppt}$ (2-methylpentane). The global uncertainty is estimated between $5 \%$ and $38 \%$.

Carbopack tube analysis was carried out by applying a gas chromatography-flame ionization detector (ATD-GC-FID, Perkin Elmer) system at the SAGE Department (IMT Lille Douai). The cartridges were previously thermo-desorbed at $350^{\circ} \mathrm{C}$ for $15 \mathrm{~min}$ with a helium flow of $20 \mathrm{~mL} \mathrm{~min}^{-1}$. This method allowed the separation and identification of up to 56 compounds, from $\mathrm{C}_{5}$ to $\mathrm{C}_{16}$ VOCs, including 7 aldehydes, 4 ketones, 10 monoterpenes, and 6 long-chain alkanes from $\mathrm{C}_{12}$ to $\mathrm{C}_{16}$. More details on the analytical technique can be found elsewhere (Ait-Helal et al., 2014; Detournay et al., 2011). VOCs can be classified according to their saturation concentration, $C^{*}$, which indicates their volatility (Ait-Helal et al., 2014; Epstein et al., 2010; Robinson et al., 2007). Here, $\mathrm{C}_{12}-\mathrm{C}_{16}$ alkanes are classified as VOCs of intermediate volatility, given their $C^{*}$ values are between $10^{3} \mu \mathrm{g} \mathrm{m}^{-3}<C^{*}<10^{6} \mu \mathrm{g} \mathrm{m}^{-3}$ (Ait-Helal et al., 2014). The detection limits lie between 1 and 13 ppt (hexadecanal) and the global uncertainty varies between $3.7 \%$ and $32.6 \%$, as detailed elsewhere (Detournay et al., 2011; Keita et al., 2018).

The application of both methods allowed the comparison of common compounds that were measured at ambient sites and sources (benzene, toluene, ethylbenzene, $\mathrm{m}+\mathrm{p}$ xylene, o-xylene, trimethylbenzenes, n-heptane, iso-octane, $\mathrm{n}$-octane, $\alpha$-pinene, $\beta$-pinene, limonene, isoprene) and the performance analysis of the analytical techniques. Furthermore, the combination of different sorbent tubes and analytical strategies allowed the quantification of a higher number of VOC species, and therefore, a more extensive analysis of source contributions.

\subsection{Metrics and calculations}

Different calculations were implemented to assess the VOC emissions and their impacts in Abidjan. Here we provide the mathematical basis for each investigated parameter. Firstly, the EFs were computed for the whole extended VOC database (56 compounds) following the methodology described in Keita et al. (2018). EFs combined with regional 
statistics were later used for the estimation of VOC emissions in Côte d'Ivoire for each source category. Secondly, the emission ratios (ERs) of each VOC species related to CO for all the emission sources were established. Finally, the reported ERs were used to evaluate the impacts on atmospheric reactivity by applying commonly used metrics.

\subsubsection{Emission factors and quantification of VOC emissions}

VOC emission factors were estimated from the concentrations measured for all the emission sources, as follows:

$\mathrm{EF}(\mathrm{VOC})=\frac{\frac{\Delta \mathrm{VOC}}{\Delta \mathrm{CO}+\Delta \mathrm{CO}_{2}} \times \mathrm{MW}_{\mathrm{VOC}}}{12} \times f_{\mathrm{c}} \times 10^{3}$,

where $\mathrm{EF}$ (VOC) is the emission factor of the specific VOC in gram per kilogram of burned fuel $\left(\mathrm{g} \mathrm{kg}^{-1}\right) ; \Delta \mathrm{VOC}=$ $[\mathrm{VOC}]_{\text {emission }}-[\mathrm{VOC}]_{\text {background }}$ is the VOC mixing ratio in the emission and background air, respectively, in parts per billion by volume (ppbv), $\mathrm{MW}_{\mathrm{VOC}}$ is the molar weight of the specific VOC (in $\mathrm{g} \mathrm{mol}^{-1}$ ), 12 is the molar weight of carbon $\left(\mathrm{g} \mathrm{mol}^{-1}\right)$, and $f_{\mathrm{c}}$ is the mass fraction of carbon in the fuel analysed. The $f_{\mathrm{c}}$ values used were obtained from the literature and applied to each source. The EFs for selected 15 VOCs were already published, and more details about the method can be found elsewhere (Keita et al., 2018). Here we applied the same method for the whole VOC database, including 56 compounds directly measured from the emission sources. For this, VOC emissions were estimated using the emission factors obtained from near-source measurements along with the statistical International Energy Agency (IEA) activity data, available for the different sources). Equation (1) was used to compute the emission factors, considering all the VOC species measured and including the mass fraction of each fuel $\left(f_{\mathrm{c}}\right)$ obtained from the literature. Additionally, the differences in fuel type and the fleet age have been considered, as well as the fleet distribution by calculating the equivalent vehicular fleet. For the road transport sector, the equivalent fleet means were calculated considering the fleet characteristics in Côte d'Ivoire, as detailed in Keita et al. (2018). These calculations were based on the information given by the Direction Generale des Transports Terrestres in Côte d'Ivoire, which considered that $60 \%$ of vehicles are old models and $77 \%$ of the total fleet is composed of light-duty vehicles. Regarding two-wheel vehicles, $60 \%$ of them are two-stroke engines, and only $40 \%$ of the total are considered recent vehicles (SIE CI, 2010). In the residential profile, we integrated the emissions measured from charcoal making, charcoal burning, and wood fuel burning sources, commonly observed at residential sites in Abidjan. Afterwards, the mean road transportation and residential profiles for Côte d'Ivoire were computed and compared with two referenced global inventories, EDGAR v4.3.2 and MACCity (Granier et al., 2011; Huang et al., 2017).

\subsubsection{Molar mass emission ratios}

ERs were obtained by dividing each VOC mixing ratio by carbon monoxide (CO) mixing ratios as follows:

$\mathrm{ER}=\frac{[\Delta \mathrm{VOC}] \mathrm{ppbv}}{[\Delta \mathrm{CO}] \mathrm{ppmv}}$.

We selected $\mathrm{CO}$ as a combustion tracer because most VOCs and $\mathrm{CO}$ are co-emitted by the target sources. Furthermore, ratios to $\mathrm{CO}$ are regularly reported in the literature for biomass burning and urban emissions (Baker et al., 2008; Borbon et al., 2013; Brito et al., 2015; Gilman et al., 2015; de Gouw et al., 2017; Koss et al., 2018; Wang et al., 2014), which are useful constraints for further comparisons. Emission ratios were calculated in ppbv of VOC per parts per million by volume (ppmv) of $\mathrm{CO}$, which is similar to a molar ratio (mmol VOC per mol CO). Molar mass (MM) emission ratios were also computed following Gilman et al. (2015). MM is the VOC mass emitted $\left(\mu \mathrm{g} \mathrm{m}^{-3}\right)$ per ppmv $\mathrm{CO}$, obtained from Eq. (2) and converted by using the VOC molecular weight (MW) $\left(\mathrm{g} \mathrm{mol}^{-1}\right)$ and the molar volume $(24.86 \mathrm{~L}$ at 1 atm and $30^{\circ} \mathrm{C}$ ). Table S1 includes the emission ratios obtained for each VOC and MW value used.

\subsubsection{VOC-OH reactivity}

The $\mathrm{OH}$ reactivity was estimated to evaluate the potential contribution of each measured VOC to the photochemical processing. VOC-OH reactivity represents the sink reaction of each VOC with the hydroxyl radical $(\mathrm{OH})$ and is equal to

$\mathrm{VOC}_{\mathrm{OH} \text { reactivity }}=\mathrm{ER} \times k_{\mathrm{OH}} \times \mathrm{CF}$,

where ER is the emission ratio for each VOC related to $\mathrm{CO}$ (ppbv per ppmv), $k_{\mathrm{OH}}$ is the secondorder reaction rate coefficient of VOC with the hydroxyl radical $\left(\times 10^{-12} \mathrm{~cm}^{3}\right.$ molecule $\left.\mathrm{e}^{-1} \mathrm{~s}^{-1}\right)$, and $\mathrm{CF}$ is the conversion factor of molar concentration $(2.46 \times$ $10^{10}$ molecule $\mathrm{cm}^{-3} \mathrm{ppbv}^{-1}$ at $1 \mathrm{~atm}$ and $25^{\circ} \mathrm{C}$ ) (Gilman et al., 2015). $k_{\mathrm{OH}}$ values for all VOC species were obtained from Atkinson and Arey (2003) and the NIST Chemical Kinetics Database (Manion et al., 2015).

\subsubsection{Ozone formation potential}

The oxidation of VOCs is often initiated by the reaction with the hydroxyl radical $\left({ }^{\circ} \mathrm{OH}\right)$, which in the presence of $\mathrm{NO}_{x}$ $\left(\mathrm{NO}+\mathrm{NO}_{2}\right)$ leads to the photochemical formation of $\mathrm{O}_{3}$. The ozone formation potential represents the ability of each VOC to produce tropospheric ozone, and it was calculated as follows:

VOC_ ozone formation potential $=\mathrm{ER} \times \mathrm{POCP}$,

where the ER is the emission ratio of each VOC related to $\mathrm{CO}$ (ppbv of VOC per ppmv of CO) and POCP is the photochemical ozone creation potentials developed in previous studies 
(Derwent et al., 2007; Jenkin et al., 2017). POCP values were obtained by simulating a realistic urban mass trajectory with the Master Chemical Mechanism (MCM). This model estimates the change in ozone production by incrementing the mass emission of each VOC (Derwent et al., 1998). POCPs for an individual VOC are estimated by quantifying the effect of a small increase in its emission on the concentration of the formed modelled ozone respective to that resulting from the same increase in the ethene emission (the POCP value for ethene is, therefore, 100). In this study, POCP values were analysed on a VOC family basis obtained from a recent study (Huang et al., 2017) or adapted from individual POCP values.

\subsubsection{Secondary organic aerosol (SOA) formation potential}

The SOA formation potential represents the propensity of each VOC to form secondary organic aerosols and is equal to

SOA_VOC formation potential $=\mathrm{ER} \times \mathrm{SOAP}$,

where ER is the emission ratio for each measured VOC related to $\mathrm{CO}$ (ppbv of VOC per ppmv of CO) and SOAP is a non-dimensional model-derived SOA formation potential (Derwent et al., 2010; Gilman et al., 2015). All SOAP values represent the modelled masses of organic aerosol that were formed per mass of VOC reacted on an equal mass emitted basis relative to toluene. Toluene was selected as the reference compound due to its well-known emissions, and it is usually documented as a critical anthropogenic SOA precursor (Derwent et al., 2010).

$\mathrm{ER}, k_{\mathrm{OH}}$, and SOAP values for each VOC and each source are detailed in Table S1. In the absence of SOAP values for specific compounds, we estimated the values (indicated in Table S1, referred to as ${ }^{\text {a }}$ ) by using those of comparable compounds based on similar chemical properties, as suggested in the study of Gilman et al. (2015).

\subsection{Ancillary data}

Meteorological observations were provided by the NOAA Integrated Surface Database (ISD; https://www.ncdc.noaa. gov/isd, last access: 6 June 2018, for more details). Daily rainfall, air temperature, and wind speed and direction measurements were recorded at the Abidjan Felix Houphouet Boigny Airport. Figure 1 gives the geographical location of the meteorological station and ambient sampling locations.

\section{Results and discussion}

\subsection{Local meteorological conditions}

Meteorological data from Abidjan, Côte d'Ivoire, are reported in Fig. 2. Weekly accumulated precipitation and weekly air temperature means were analysed during 2016.
Meteorological conditions in Abidjan are also affected by the monsoon phenomenon which establishes two well-defined seasons: a wet season between March and August and a dry season from November to February. The weekly mean air temperature observed was between 24.6 and $29.4{ }^{\circ} \mathrm{C}$, reaching a maximum during the beginning of the wet season (Fig. 2). The precipitation pattern shows an increased rate during the monsoon period; however, negative anomalies were observed this year compared with the previous ones (Knippertz et al., 2017). Observed wind patterns during the field campaign showed a predominant contribution from the south-westerly sector with maximum speed during daytime of up to $13 \mathrm{~ms}^{-1}$. The high wind speed records reported in Abidjan are higher than those observed in other polluted urban atmospheres (Dominutti et al., 2016; Salameh et al., 2016a; Zhang et al., 2014).

\subsection{VOCs in the Abidjan atmosphere}

Our analysis relies on the 15 VOC species already listed in Keita et al. (2018, only for emission sources), and these were measured in both ambient air and at emission sources. The VOCs include eight aromatic hydrocarbons, three monoterpenes, three alkanes, and isoprene, which span a wide range of reactivity and represent the various types of VOCs expected to be released by fossil/non-fossil fuel combustion and biogenic emissions.

\subsubsection{Ambient concentrations and spatial distribution}

The ambient concentration sum of the 15 quantified VOCs ranged from 6.25 to $72.13 \mu \mathrm{g} \mathrm{m}^{-3}$ (see size-coded pie chart, Fig. 3). Higher VOC concentrations were reported in KSI, BIN, CRE, and PL sites (Fig. 3). The predominant VOCs are toluene $\left(4.18 \pm 3.55 \mu \mathrm{g} \mathrm{m}^{-3}\right), \mathrm{m}+\mathrm{p}$-xylene $(4.05 \pm$ $\left.3.41 \mu \mathrm{g} \mathrm{m}^{-3}\right)$, iso-octane $\left(2.59 \pm 3.37 \mu \mathrm{g} \mathrm{m}^{-3}\right)$, benzene $\left(1.00 \pm 0.41 \mu \mathrm{g} \mathrm{m}^{-3}\right)$, ethylbenzene $\left(0.93 \pm 0.86 \mu \mathrm{g} \mathrm{m}^{-3}\right)$, and limonene $\left(0.77 \pm 0.76 \mu \mathrm{g} \mathrm{m}^{-3}\right)$. Overall, anthropogenic VOCs dominated the ambient composition by factors of 5 to 20 compared to biogenic ones. BTEX (benzene, toluene, ethylbenzene, and $\mathrm{m}+\mathrm{p}$ and o-xylenes), a subgroup of aromatic VOCs, usually makes up a significant fraction of the VOC burden in urban atmosphere (Borbon et al., 2018; Boynard et al., 2014; Dominutti et al., 2016). They are emitted by fossil fuel combustion from transport and residential sources as well as evaporation processes such as fuel storage and solvent uses (Borbon et al., 2018). Here their contribution ranged from $35 \%$ to $76 \%$ of the total VOC burden measured at the ambient sites. Therefore, the following discussion will only focus on BTEX as representative of all measured anthropogenic VOC patterns. Figure 3 shows the spatial distribution of the total VOC concentrations at each site and detailed by the BTEX composition. Firstly, a spatial heterogeneity of the total measured VOC concentration (total values on pie chart, Fig. 3) is depicted in the Abidjan 
(a)

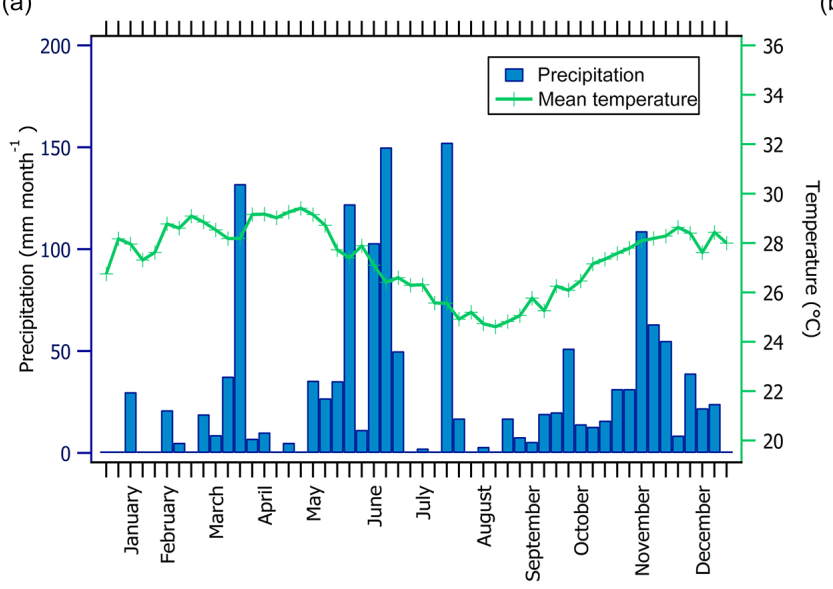

(b)

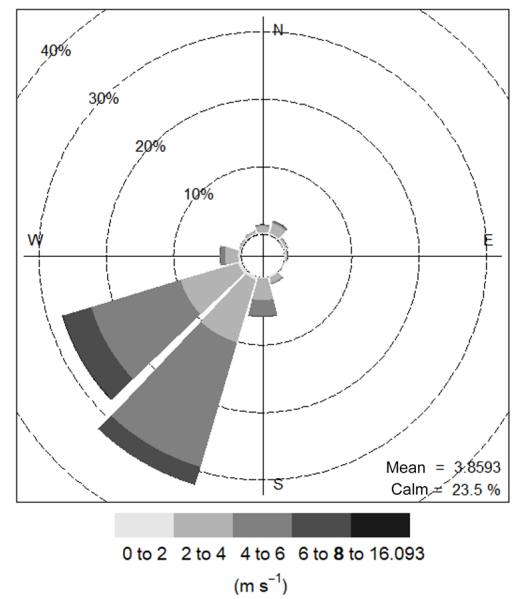

Figure 2. Meteorological data observed in Abidjan, Côte d'Ivoire. The figure represents (a) the weekly accumulated precipitation (in mm month ${ }^{-1}$ ) and weekly mean air temperature (in ${ }^{\circ} \mathrm{C}$ ) and (b) the wind speed (in $\mathrm{m} \mathrm{s}^{-1}$ ) and direction observed (deg), during the field campaigns (2016). Data were downloaded from the National Centers for environmental information site (NCDC), NOAA, and recorded at Abidjan International Airport (see location in Fig. 1).

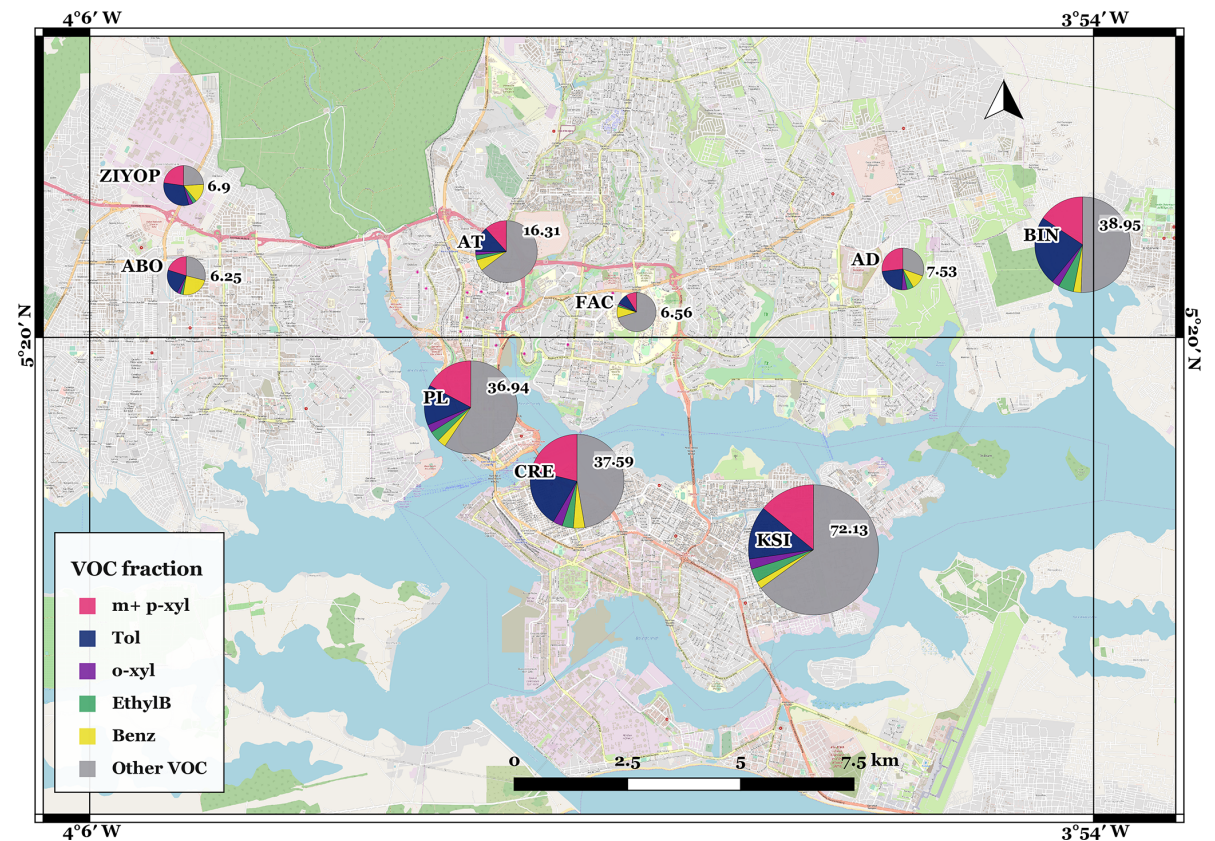

Figure 3. Spatial distribution of VOCs measured at ambient sites in Abidjan, size-coded by the sum of VOCs (in $\mu \mathrm{g} \mathrm{m} \mathrm{m}^{-3}$ ) and color-coded by the relative contribution of BTEX compounds (\% in mass), namely $m+p$-xylene $(m+p$-xyl), toluene (Tol), o-xylene (o-xyl), ethylbenzene (EthylB), benzene (Benz), and other VOCs. Values shown in each pie chart represent the total VOC concentration measured at the sampling point. Ambient site names and characteristics are presented in Table 2. Map: () OpenStreetMap contributors (OpenStreetMap contributors, 2015).

district. This spatial heterogeneity has been already pointed out by recent studies performed in Abidjan for other atmospheric pollutants (Bahino et al., 2018; Djossou et al., 2018). While a spatial heterogeneity was also observed in aerosol concentrations (Djossou et al., 2018), maximum aerosol concentrations were reported near domestic fires (similar to KSI) and landfill sites (AD), showing a different pattern than the one observed for the VOC concentrations. Besides the dilution processes, the spatial distribution of total VOC concentrations seems to be related to the proximity of emission sources, affecting ambient VOC concentrations in the different sampling locations. For example, higher total VOC 


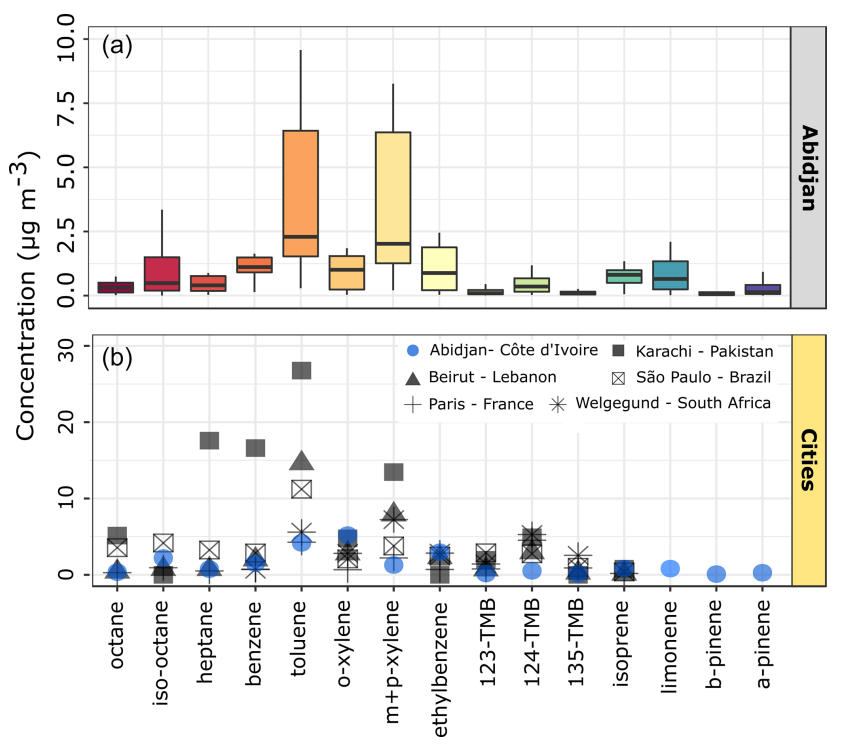

Figure 4. Boxplot showing the VOC concentrations $\left(\mu \mathrm{g} \mathrm{m}^{-3}\right)$ at Abidjan ambient sites (a). The middle line in each box plot indicates the median (50th percentile), the lower and upper box limits represent the 25th and 75th quartiles, respectively, and the whiskers the $99 \%$ coverage assuming the data have a normal distribution. (b) shows the mean concentrations reported in other cities worldwide, such as Abidjan - Côte d'Ivoire (this study), Paris - France (AIRPARIF, 2016), São Paulo - Brazil (Dominutti et al., 2016), Beirut - Lebanon (Salameh et al., 2014), Karachi - Pakistan (Barletta et al., 2002), and Welgegund - South Africa (Jaars et al., 2014).

concentrations were mainly observed in the central urban area (like KSI, CRE, and PL) where the density of emission sources increases.

Second, $\mathrm{m}+\mathrm{p}$-xylene and toluene dominate the ambient distribution of BTEX, ranging from $9 \%$ to $27 \%$ and $8 \%$ to $31 \%$ of the total VOC, respectively. BTEX composition is consistent between PL, CRE, BIN, and KSI sites with high VOC loads, while an enrichment in benzene concentrations is observed at FAC, ABO, ZYOP, AT, and AD sites (from $16 \%$ to $30 \%$ contribution). The BTEX composition can be affected by emissions and chemistry. The toluene-to-benzene ratio is a useful indicator of either traffic and non-traffic source or chemistry effects. On the one hand, the tolueneto-benzene at PL, CRE, BIN, and KSI sites is higher than 4, which suggests the influence of sources other than traffic like industrial sources. On the other hand, the toluene-to-benzene lies between 0.8 and 1.9 at lower VOC load sites (FAC, ABO, ZYOP, AT, and AD) (Brocco et al., 1997; Heeb et al., 2000; Muezzinoglu et al., 2001). These values are closer to the one usually observed at traffic emissions. There is no visible effect of chemistry here, especially on higher aromatics like $\mathrm{C}_{8}$ aromatics with a shorter lifetime whose contribution stays almost constant regardless of the site.

The mean ambient concentrations observed in Abidjan for alkanes and aromatics were compared with those observed in other cities worldwide (Fig. 4). On the one hand, mean concentrations in Abidjan depicted lower values when compared with those measured in other cities (Fig. 4). Keita et al. (2018) pointed out the high emissions observed in Abidjan sources. In their study, road transport and wood burning VOC emission factors spanned 2 to 100 orders of magnitude, respectively, when compared with those from the literature. Our ambient observations suggest that wind speeds have an important role in the mixing and dilution of the anthropogenic emissions leading to low VOC concentrations in the Abidjan atmosphere. As was pointed out in the meteorological description, the proximity of Abidjan to the ocean and the intrusion of the sea-breeze circulation can facilitate the dispersion processes and, consequently, the urban emissions dilution. Indeed, Deroubaix et al. (2019) analysed the regional dispersion of urban plumes from southern West African coastal cities, i.e. Abidjan, where the inland northward transport of anthropogenic coastal pollutants along with biomass burning emissions were observed.

On the other hand, a reasonably good agreement in the relative composition of alkanes and aromatics is observed, showing the same distribution in most cities, except for Karachi, where higher contributions of heptane and benzene were measured (Barletta et al., 2002). Observed concentrations of hydrocarbons result from primary emissions, chemical processing, and dilution in the atmosphere. Dilution affects equally all the compounds by decreasing absolute levels without altering their composition. Chemistry can be neglected because the transport time between major urban sources and receptor sites is usually less than the compound lifetimes (here the shortest lifetime for trimethylbenzene is $4.3 \mathrm{~h}$ ). Finally, only emissions are expected to significantly alter the hydrocarbon composition. However, the composition is the same regardless of the location. Such commonality suggests that the urban hydrocarbon composition worldwide is controlled by emissions from fossil fuel combustion and, gasoline-powered vehicles in particular (see also next section). Finally, the ambient hydrocarbon distributions in Abidjan are noticeably similar to other northern mid-latitude megacities, suggesting that emissions from fossil fuel combustion for alkanes and aromatics dominate over other region-specific sources. These results are also consistent with previous studies comparing different databases worldwide without including an African city like Abidjan (Borbon et al., 2002; Dominutti et al., 2016; von Schneidemesser et al., 2010). Even if emissions can be different in intensity (number of vehicles for instance), the hydrocarbon composition seems to be similar in the different urban atmospheres.

\subsubsection{Ambient composition versus emission source profiles}

A comparative approach was carried out between ambient and source measurement compositions with the purpose 

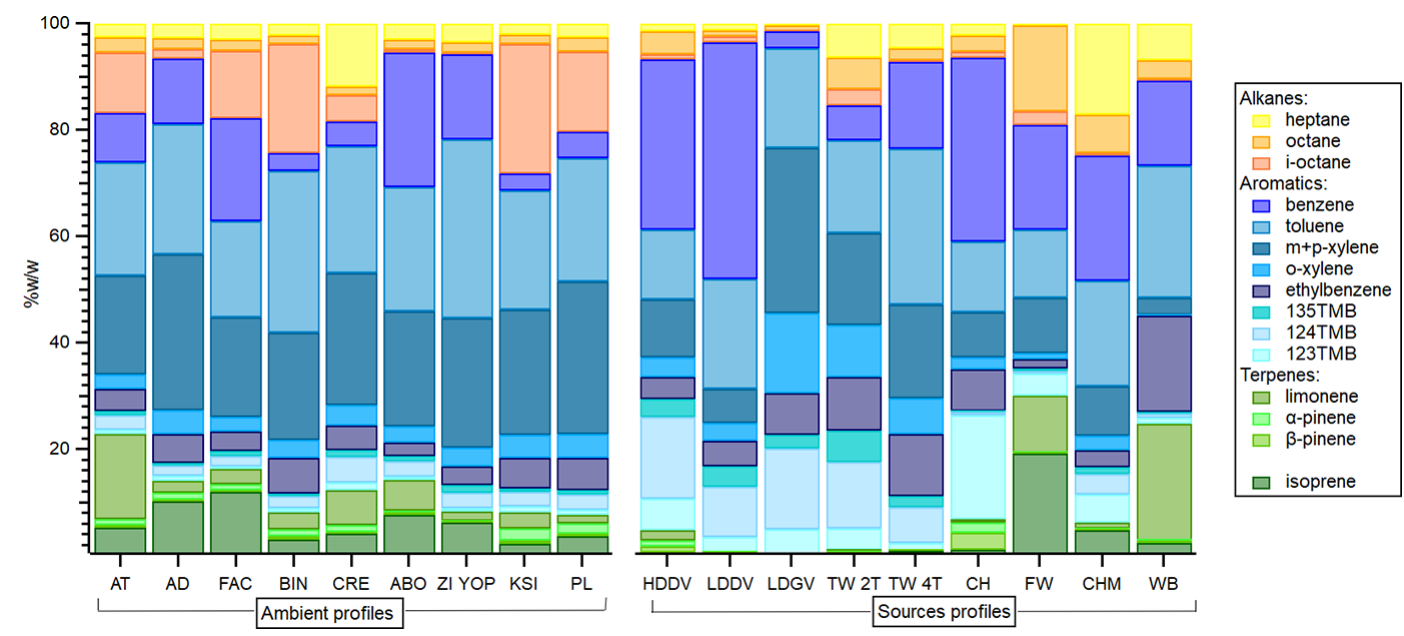

Figure 5. Relative concentration comparison between ambient measurements and emission source profiles of VOCs measured in Abidjan, Côte d'Ivoire. Orange- and yellow-based colours represent the contributions of alkanes, blue-based colour aromatics, and green-based colour terpenes and isoprene.

of detecting emission source fingerprints in ambient VOC profiles. Figure 5 shows the relative mass contribution of VOC profiles observed at the nine urban sites together with those obtained from the emission sources. While a noticeable variability in the contribution of emission sources is observed, smoother differences are depicted between the ambient sites. This result reinforces the similar BTEX profiles discussed in Sect. 3.2.1, where the mixing and dilution process were suggested as the main drivers in the control of ambient emissions. Trimethylbenzenes (124-TMB, 135$\mathrm{TMB}$, and 123-TMB), mainly observed in road transport emissions, display a dissimilar profile showing higher fractions from sources than ambient sites (Fig. 5). These differences might be related to the short lifetime of these compounds (around $4 \mathrm{~h}$ ), with a reaction rate ranging from 1.8 to $8.8 \times 10^{-15} \mathrm{~cm}^{3}$ molecule ${ }^{-1} \mathrm{~s}^{-1}$ (Atkinson and Arey, 2003). Their reactivity implies a faster reaction in the atmosphere and losses of these species from the emission to the receptor.

On the other hand, in most of the cases, ambient profiles showed higher contributions of alkanes, monoterpenes, and isoprene, likely associated with the contribution from different anthropogenic and biogenic sources. The presence of terpenes and isoprene in the profile of all emission sources is notable, mainly in those associated with domestic burning processes, such as charcoal, waste, and wood fuel burnings (Fig. 5). The terpene emissions from biomass burning were already identified in several studies as they are common species emitted by combustion processes (Gilman et al., 2015; Simpson et al., 2011). Additional studies based on African biomass emissions also reported concentrations of limonene and $\alpha$-pinene higher than isoprene (Jaars et al., 2016; Saxton et al., 2007).

For the selected VOC species, aromatic compounds represent the higher fraction from ambient and source profiles, contributing $31 \%$ to $75 \%$ (Fig. 5). Comparing the same VOC species in emission sources versus ambient profiles, we found a similarity to the two-wheel vehicle and domestic fire profiles like wood fuel burning and charcoal burning sources. Nevertheless, the VOC ambient profiles obtained from the sites did not show a contrasted difference despite the differences in the activities conducted nearby.

\subsection{Molar mass of measured VOC emissions in Abidjan}

Here we compare the composition and magnitude of anthropogenic emissions as a function of molar mass emission ratios as described in Sect. 2.3.2, which is a readily calculated property used to quantify anthropogenic emissions (Gilman et al., 2015). For this analysis, our expanded VOC database of 56 species was considered, including 12 terpenes, VOCs of intermediate volatility (IVOCs from $\mathrm{C}_{12}$ to $\mathrm{C}_{16} \mathrm{n}$-alkanes), ketones, and aldehyde ( $>\mathrm{C}_{6}$ ) compounds for all sources (Tables 1 and $\mathrm{S} 1$ ). Species groups were classified according to GEIA groups (Huang et al., 2017) according to the chemical function of each VOC family (Table S2). In this way, molar masses were also grouped by VOC family from individual values (Table S1). Since the VOCs of intermediate volatility (IVOCs) do not have a specific classification, they were integrated into the group of heavy alkanes (VOC6). Note also that the most volatile fraction of OVOC, which usually represents the major fraction, is not represented here in the VOC22 and VOC23 categories. The associated contribution should be analysed as the lower expected limit. Figure 6 shows the contribution of VOC groups to the measured molar mass and the total molar mass of each source, while Fig. 7a-d (upper panel) compared the magnitude of measured molar masses for the four leading sectors. As already described in the previous section, the distribution reported in Fig. 6 reveals the predominance of aromatic mo- 


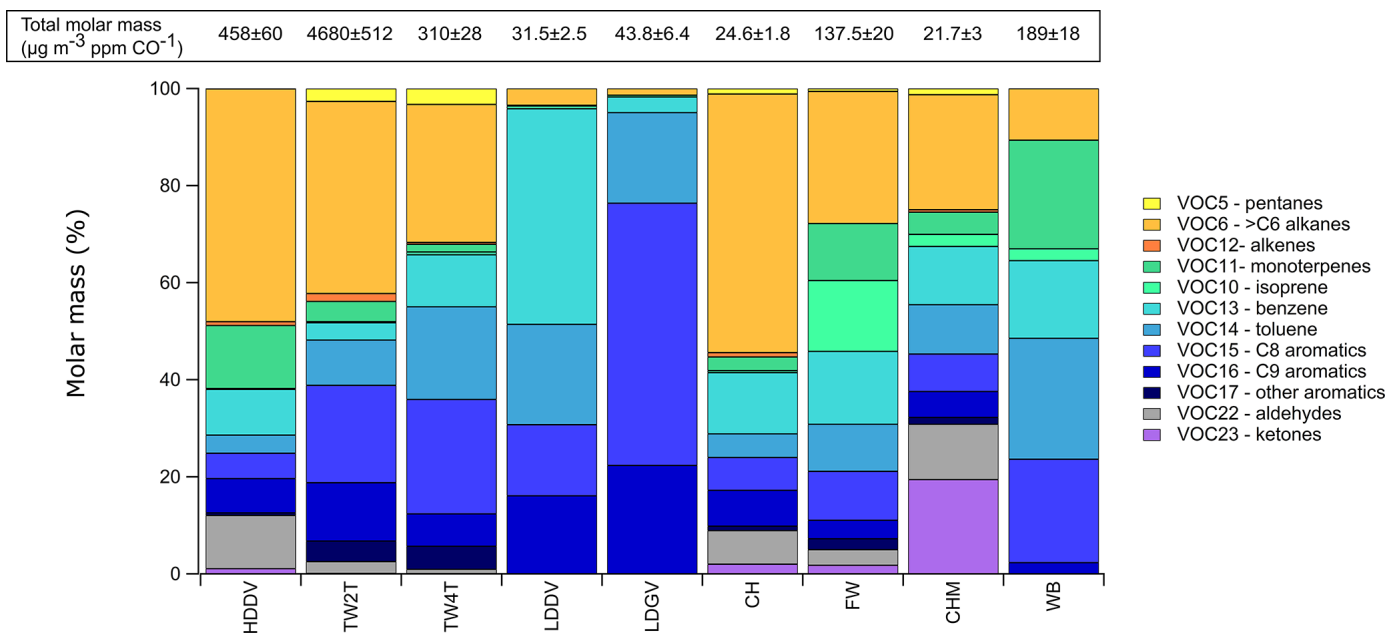

Figure 6. Contribution of VOC reported in Table S1 to the measured molar mass of anthropogenic sources analysed in Abidjan, aggregated in VOC families (Table S2). The emission sources under analysis are heavy-duty diesel vehicles (HDDV), two-wheel two-stroke vehicles (TW2T), two-wheel four-stroke vehicles (TW4T), light-duty diesel vehicles (LDDV), light-duty gasoline vehicles (LDGV), charcoal burning $(\mathrm{CH})$, wood fuel burning $(\mathrm{FW})$, charcoal making (CHM), and waste burning (WB). Values in the upper panel represent the total measured molar mass (in $\mu \mathrm{g} \mathrm{cm}^{-3} \mathrm{ppm} \mathrm{CO}^{-1}$ ) of the respective anthropogenic source.

Table 1. Description of the emission sources measured and evaluated in Abidjan, Côte d'Ivoire.

\begin{tabular}{lllll}
\hline Reference & Sub-group & Description & source & type \\
\hline HDDV & & Heavy-duty diesel vehicles & Diesel emissions & Road transport \\
& HDDV-T & Diesel trucks & Diesel emissions & Road transport \\
& HDDV-B & Diesel buses & Diesel emissions & Road transport \\
LDDV & & Light-duty diesel vehicles & Diesel emissions & Road transport \\
LDGV & & Light-duty gasoline vehicles & Gasoline emissions & Road transport \\
TW & TW2T & Two-wheel two-stroke & a mixture of smuggled oil and gasoline & Road transport \\
& TW4T & Two-wheel four-stroke & a mixture of smuggled oil and gasoline & Road transport \\
CH & & Charcoal & Charcoal burning & Residential \\
FW & & Wood fuel burning & Hevea brasiliensis & Residential \\
CHM & & Charcoal making & Charcoal fabrication & Residential \\
WB & & Waste burning & Domestic landfill burning & Waste burning \\
\hline
\end{tabular}

lar masses (VOC13-VOC17), ranging from $26 \%$ to $98 \%$. The prevalence of these compounds is predominantly observed in gasoline-fuelled vehicles, like gasoline light-duty (LDGV) and two-wheel (TW) vehicles and diesel light-duty vehicles (LDDV). Alkanes (VOC5 + VOC6) also comprise a noticeable molar mass fraction, dominating in two-wheel two-stroke vehicle, heavy-duty vehicle, and charcoal related sources (by $40 \%, 47 \%$ and $53 \%$, respectively).

A considerable IVOC contribution from the emission of heavy-duty vehicles was observed, with IVOCs dominating the VOC6 fraction by $30 \%$ (considering that VOC6 represents $47 \%$ of the total emissions from this source).

Interestingly, and as already discussed in Sect. 3.2.2, monoterpenes (VOC11) comprised $11 \%, 13 \%$, and $22 \%$ contributions in wood fuel burning, heavy-duty vehicle, and waste burning sources, respectively (FW, HDDV, and WB, Figs. 6 and $7 \mathrm{~b}-\mathrm{c}$ ). Terpenes in biomass burning sources were already pointed out as the most significant emitted compounds together with furans and aromatics in chamber experiments (Koss et al., 2018). Nevertheless, to the extent of our knowledge, their presence in road transport or open waste burning emissions remains unexplored. Regarding OVOCs (VOC22), they were observed in a smaller fraction (less than $7 \%$ ) apart from heavy-duty vehicles, which contributes $11 \%$ of the total measured molar mass. Previous studies have reported OVOCs as the main fraction in biomass burning emissions (Akagi et al., 2011; Gilman et al., 2015; Yokelson et al., 2013). Moreover, Sekimoto and co-workers also analysed the VOC emission profiles depending on the pyrolysis temperature, showing enrichment of terpenes and nonaromatic oxygenates under high-temperature conditions and an increase in oxygenated aromatics under low-temperature fires (Sekimoto et al., 2018). Comparing the burning-related sources such as wood fuel burning with previous studies, a 


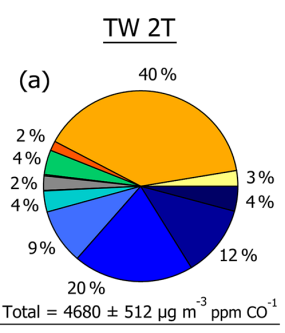

(e)

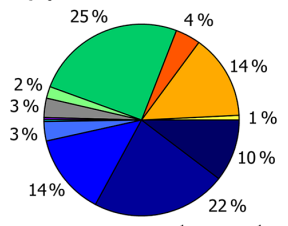

$\underline{\text { Total }=488 \pm 43 \mathrm{~s}^{-1} \mathrm{ppm} \mathrm{CO}^{-1}}$

(i)

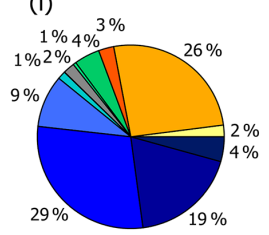

Total $=80346 \mathrm{POCP}_{\mathrm{ppm} \mathrm{CO}} \mathrm{CO}^{-1}$

(m)

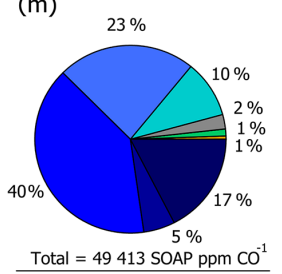

$\underline{\text { HDDV }}$

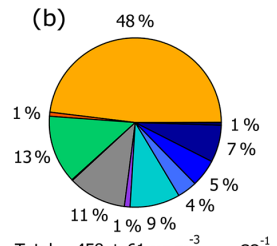

Total $=458 \pm 61 \mathrm{\mu g} \mathrm{m}^{-3} \mathrm{ppm} \mathrm{CO}^{-1}$

(f)

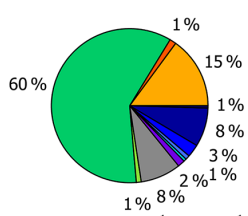

Total $=70 \pm 12 \mathrm{~s}^{-1} \mathrm{ppm} \mathrm{CO}^{-1}$

(j)

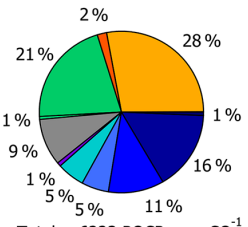

Total $=6223 \mathrm{POCP}_{\mathrm{ppm} \mathrm{CO}}{ }^{-1}$

(n)

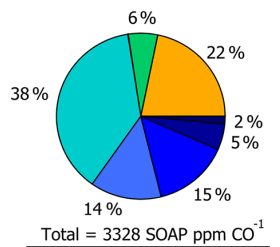

$\underline{\text { WB }}$

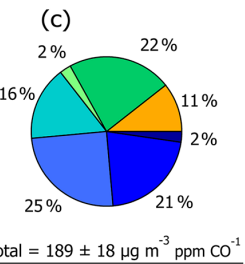

(g)

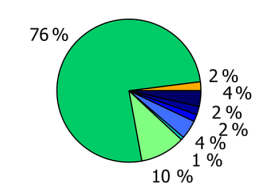

Total $=40.56 \pm 8.7 \mathrm{~s}^{-1} \mathrm{ppm} \mathrm{CO}^{-1}$

(k)

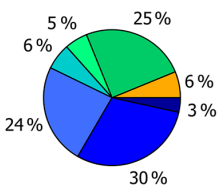

Total $=3330$ POCP ppm CO

(o)

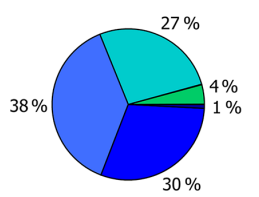

Total $=3281$ SOAP ppm CO ${ }^{-1}$

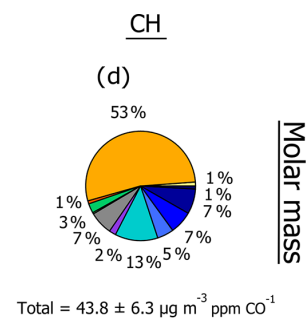

(h)

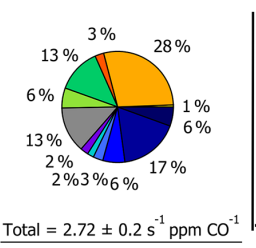

(I)

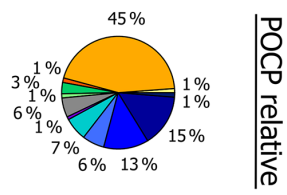

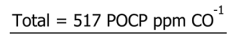

(p)

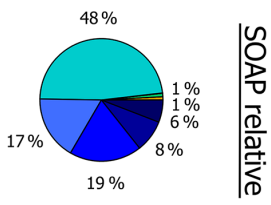

Total $=335$ SOAP ppm CO $^{-1}$

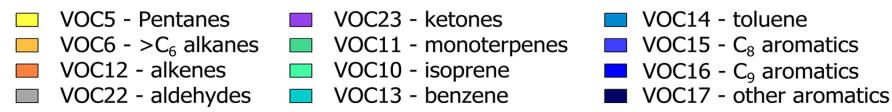

Figure 7. Contributions of VOC emission ratios to (a)-(d) the measured molar mass, (e)-(h) OH reactivity, (i)-(l) relative ozone formation potential POCP, and (m)-(p) relative SOA formation potential, aggregated in VOC families. Absolute totals for each source are shown below each pie chart in the respective units.

lower total measured molar mass was observed in our study than those obtained in the US fuels, by factors of 33 to 117 (Gilman et al., 2015). In that work, Gilman and co-workers have shown that OVOCs represent $57 \%$ to $68 \%$ of the total measured molar mass. A different pattern is observed in this study, likely related to the limitation of VOC species measurements by the sampling method deployed, which allows the collection of a limited number of aldehydes $\left(>\mathrm{C}_{6}\right)$ and other oxygenated compounds as well. Thus, our total molar mass estimation for the sources in Abidjan should be considered a lower limit since additional contributions could be expected from other unknown emitted VOCs, such as OVOCs, alkenes, and nitrogenated VOCs.

Four sources (TW2T, HDDV, WB, and $\mathrm{CH}$ ) that represent the leading sectors in the region (road transportation, waste burning, and charcoal burning emissions) were selected, in order to analyse the magnitude of emissions as a function of molar mass and their potential impacts related to African emissions (next section). Figure 7a-d show the relative composition and the total molar mass of the measured VOC $\left(\mu \mathrm{g} \mathrm{m}^{-3}\right)$ emitted per ppmv of CO. Two-wheel two-stroke vehicles (TW2T) disclosed the highest molar mass emissions $\left(4680 \pm 512 \mu \mathrm{g} \mathrm{m}^{-3} \mathrm{ppmv} \mathrm{CO}^{-1}\right.$, Fig. 7a-d). TW2T emissions were 10 to 200 times higher than any other source here analysed, such as heavy-duty vehicle $\left(458 \pm 60 \mu \mathrm{g} \mathrm{m}^{-3} \mathrm{ppmv}^{-1}\right)$, wood fuel burning $\left(31.5 \pm 2.50 \mathrm{\mu g} \mathrm{m}^{-3} \mathrm{ppmv} \mathrm{CO}^{-1}\right)$, charcoal burning (43.8 \pm $\left.6.37 \mathrm{\mu g} \mathrm{m}^{-3} \mathrm{ppmv} \mathrm{CO}^{-1}\right)$, and light-duty vehicle (137.5 \pm $20 \mathrm{\mu g} \mathrm{m}^{-3}$ ppmv CO$^{-1}$ ) emissions (Fig. 6). While aromatics (VOC13-VOC17) seem to dominate the molar mass fraction for most sources, their contributions are dissimilar, dominated by benzene (VOC13) and toluene (VOC14) in burning- 
Table 2. Geographical location and characteristics of ambient measurement sites in Abidjan, Côte d'Ivoire.

\begin{tabular}{|c|c|c|c|c|}
\hline ID & Site location & Longitude & Latitude & Activity \\
\hline AT & Adjame & $04^{\circ} 01^{\prime} 04^{\prime \prime} \mathrm{W}$ & $05^{\circ} 21^{\prime} 14^{\prime \prime} \mathrm{N}$ & $\begin{array}{l}\text { Traffic site. Site near a gbaka public trans- } \\
\text { port station; regular traffic jams; obsolete pub- } \\
\text { lic transport vehicles (gbaka, shared taxis and } \\
\text { buses); human activities }\end{array}$ \\
\hline $\mathrm{AD}$ & Akouédo & $03^{\circ} 56^{\prime} 16^{\prime \prime} \mathrm{W}$ & $05^{\circ} 21^{\prime} 12^{\prime \prime} \mathrm{N}$ & $\begin{array}{l}\text { Landfill waste burning } \\
\text { Uncontrolled landfill, continuous waste burning } \\
\text { of all types of waste }\end{array}$ \\
\hline FAC & Cocody & $03^{\circ} 59^{\prime} 27^{\prime \prime} \mathrm{W}$ & $05^{\circ} 20^{\prime} 42^{\prime \prime} \mathrm{N}$ & $\begin{array}{l}\text { Residential. } \\
\text { University residences; electric vehicles; new } \\
\text { personal vehicles; use of liquefied petroleum } \\
\text { gas (LPG) for cooking }\end{array}$ \\
\hline BIN & Bingerville & $03^{\circ} 54^{\prime} 07^{\prime \prime} \mathrm{W}$ & $05^{\circ} 21^{\prime} 30^{\prime \prime} \mathrm{N}$ & $\begin{array}{l}\text { Urban Background } \\
\text { Far from traffic, near to Ebrié Lagoon }\end{array}$ \\
\hline CRE & Treichville & $04^{\circ} 00^{\prime} 10^{\prime \prime} \mathrm{W}$ & $05^{\circ} 18^{\prime} 41^{\prime \prime} \mathrm{N}$ & Green urban area, Near to Ebrié Lagoon; windy \\
\hline $\mathrm{ABO}$ & Abobo & $04^{\circ} 04^{\prime} 10^{\prime \prime} \mathrm{W}$ & $05^{\circ} 26^{\prime} 08^{\prime \prime} \mathrm{N}$ & $\begin{array}{l}\text { Traffic + residential } \\
\text { Townhall, near to the big market of Abobo. Old } \\
\text { communal taxis and minibuses in a crowded } \\
\text { crossroad, human activities }\end{array}$ \\
\hline ZI YOP & Yopougon & $04^{\circ} 04^{\prime} 52^{\prime \prime} \mathrm{W}$ & $05^{\circ} 22^{\prime} 12^{\prime \prime} \mathrm{N}$ & $\begin{array}{l}\text { Industrial area } \\
\text { Heavy industries (cement plants) and light in- } \\
\text { dustries (agro-industries, plastic and iron pro- } \\
\text { cessing, pharmaceutical and cosmetics indus- } \\
\text { tries); heavy goods vehicles, traffic jams }\end{array}$ \\
\hline KSI & Koumassi & $03^{\circ} 57^{\prime} 20^{\prime \prime} \mathrm{W}$ & $05^{\circ} 17^{\prime} 52^{\prime \prime} \mathrm{N}$ & $\begin{array}{l}\text { Domestic fires + traffic } \\
\text { Residential site mainly influenced by domestic } \\
\text { activities, fire-wood, and charcoal; old vehicles. }\end{array}$ \\
\hline PL & Plateau & $04^{\circ} 01^{\prime} 26^{\prime \prime} \mathrm{W}$ & $05^{\circ} 19^{\prime} 33^{\prime \prime} \mathrm{N}$ & $\begin{array}{l}\text { Traffic/administrative } \\
\text { City centre, crossroad with traffic jams; light- } \\
\text { duty vehicles, near the train station }\end{array}$ \\
\hline
\end{tabular}

related sources and by xylenes (VOC15) and trimethylbenzenes (VOC16) in traffic-related ones.

\subsection{Implications for atmospheric reactivity}

The estimation of the impact on atmospheric chemistry of measured VOC emissions is based on the three metrics described in Sect. 2.3.

\subsubsection{OH reactivity of measured VOC emissions}

Figure $7 \mathrm{e}-\mathrm{h}$ show the fractional contributions and total VOC-OH reactivity per ppmv of $\mathrm{CO}$ for the selected sources. The highest total reactivity is observed from the emissions of two-wheel two-stroke vehicles (TW2T, $488 \pm$ $43 \mathrm{~s}^{-1}$ ppmv $\mathrm{CO}^{-1}$ ), outpacing other sources by factors of 7 to 170 . This disclosed difference is related to the high ERs observed for the more reactive species, like terpenes (VOC11) and $\mathrm{C}_{8}$ and $\mathrm{C}_{9}$ aromatics (VOC15 and VOC16, respectively). Terpenes (VOC11) and aromatics (VOC13VOC17) altogether are the dominant sink of $\mathrm{OH}$, contributing $47 \%$ to $87 \%$ of the total calculated $\mathrm{OH}$ reactivity. Individually, terpenes governed the $\mathrm{OH}$ reactivity in open waste burning emissions $(76 \%)$ and heavy-duty diesel vehicles $(60 \%)$ (Fig. $7 f-g)$. When compared with other sources, a singular profile is observed for charcoal burning emissions where aldehydes (VOC22, $13 \%$ ) and heavier alkanes (VOC6, $28 \%$ ) have a higher contribution than in other emission sources. The modest presence of alkenes in the VOC$\mathrm{OH}$ fractional analysis, well-known for their high reactivity effects, is related to the limitation of the sampling method which does not allow the collection of light alkene species. We might expect a high contribution of alkenes adding to the terpene burden. 


\subsubsection{Ozone formation potential of measured VOC emissions}

Overall, the fractional ozone formation distribution is dominated by aromatics (VOC13 to VOC17) in all sources, by $38 \%$ to $63 \%$. Alkanes (VOC6) represent a significant contribution in charcoal burning, heavy-duty diesel vehicles, and two-wheel two-stroke vehicles, accounting for $45 \%$, $28 \%$, and $26 \%$, respectively. It is important to note the terpene (VOC11) contribution, coming not only from burning sources, but also from the road transportation sector (Fig. 7i1). Aldehydes (VOC22) are well-known due to their high reactivity in the atmosphere (Atkinson and Arey, 2003; Sommariva et al., 2011), and some of these species have shown a large impact on ozone formation and chemistry. In our estimation, we can observe the contribution of these compounds mainly from diesel (HDDV) and charcoal burning sources $(\mathrm{CH})$. The total potential ozone was calculated for each source, showing most of the time a dominant contribution from two-wheel two-stroke vehicles (80343 POCP per ppmv $\mathrm{CO}^{-1}$ ), which is 13,24 , and 150 times higher than the potential impact in ozone formation derived from heavy-duty vehicles, waste burning, and charcoal burning emissions, respectively.

\subsubsection{SOA formation potential of measured VOC emissions}

Figure $7 \mathrm{~m}-\mathrm{p}$ show the composition and mean SOA formation potentials of VOC families emitted by each selected source. As can be expected, charcoal burning has the lowest SOAP values (335 SOAP per ppmv $\mathrm{CO}^{-1}$ ), compared with two-wheel two-stroke vehicle, heavy-duty vehicle, and waste burning sources, whose SOAPs values are 147, 10, and 9 times greater, respectively. Globally, aromatics (VOC13VOC17) governed the SOA formation in our estimations, by $72 \%$ to $98 \%$. Interestingly, terpenes (VOC11) represented a minor contribution in the SOA formation, presenting a SOAP index lower than for aromatic species. It represents approximately $20 \%$ of the SOAP for toluene (VOC14). Despite the well-known role of terpenes as SOA precursors (AitHelal et al., 2014), the method used here is not able to correctly quantify their contributions to SOA formation. The differences between SOAP values and measured aerosol yield were already pointed out by Gilman and co-authors (Gilman et al., 2015), who performed some sensitivity tests in order to harmonize SOAP and aerosol yields. We performed the same analysis here, adjusting the SOAP terpene values to be $10 \%$ higher. The results in total SOAP per ppmv of CO did not show considerable increases in any of the sources, expanding the total SOAP up to $1 \%$. Similar results were observed for fractional distribution, so that the changes in terpene SOAPs (VOC11) did not show any substantial change in the VOC contribution for SOA formation. These findings are in agreement with those identified in the study of Gilman et al. (2015), suggesting an underestimation in the fractional contribution of terpenes to the potential formation of organic aerosols over the southern West African region.

\subsection{Quantification of VOC emissions}

Anthropogenic VOC emissions were quantified by considering the complete VOC dataset, which includes the $56 \mathrm{com}$ pounds analysed, aldehydes, IVOCs and terpene species. Mean residential emissions are also integrated and compared with those from the EDGAR v4.3.2 inventory. Additionally, we incorporate the residential and road transport profiles provided by the MACCity inventory (Granier et al., 2011), available in the ECCAD-GEIA database (http://eccad.aeris-data. fr, last access: 28 May 2018). The main differences between both global inventories are related to the speciation level of VOC families. MACCity considers all the aromatics in the same VOC group; thus, we provide here the sum of VOC13 to VOC17 families (Table S2) to compare it with the aromatics group from our quantification.

Figure 8 exhibits the speciated emissions calculated for Côte d'Ivoire along with those provided by the two emission inventories. Globally, the discrepancies already highlighted in the previous analysis are exacerbated by introducing the complete VOC database. Calculated residential emissions are greater by factors of 14 and 43 when compared with EDGAR v4.3.2 and MACCity, respectively (Fig. 8a). In terms of composition, the main differences observed are related to the VOC22 group (aldehydes). This group discloses a higher contribution by a factor of 5 in the EDGAR inventory, accounting for $64 \%$ of the total emission. There is also a disparity in the contribution from aromatics (sum of VOC13 to VOC17) and alkenes (VOC12), which reveals a more substantial influence in the MACCity profile $(58 \%$ and $22 \%$, respectively) (Fig. 8a). This disparity could be related to the few VOC species that were analysed for the VOC12 group in our study. Nevertheless, aromatics dominate the fractional contribution in our calculated emissions (39\%), especially toluene (VOC14) and $\mathrm{C}_{8}$ aromatics (VOC15) $(11 \%$ and $10 \%$, respectively). Alkanes (> VOC6 alkanes) show a more significant contribution in the residential profile, in which IVOCs contribute $20 \%$ of the total calculated alkanes obtained by our estimations.

Regarding the road transportation sector, total calculated emissions are higher than the global inventories by factors of 100 and 160 for EDGAR and MACCity, respectively (Fig. 8a). A moderate agreement is observed with speciation (Fig. 8b). Aromatics and alkanes are the main contributions for all profiles in different proportions. Our estimates report the most significant contributions in $\mathrm{C}_{8}$ aromatics (VOC15), $\mathrm{C}_{9}$ aromatics (VOC16), and toluene (VOC14), with $25 \%$, $14 \%$, and $10 \%$ contributions, respectively (Figs. 8c and 9). In comparison, EDGAR v4.3.2 shows a contribution of $9 \%$ for VOC15, $3.5 \%$ for VOC16, and $13 \%$ for VOC14 (Fig. 9). Road transport profiles also reproduce the anomalies in the 

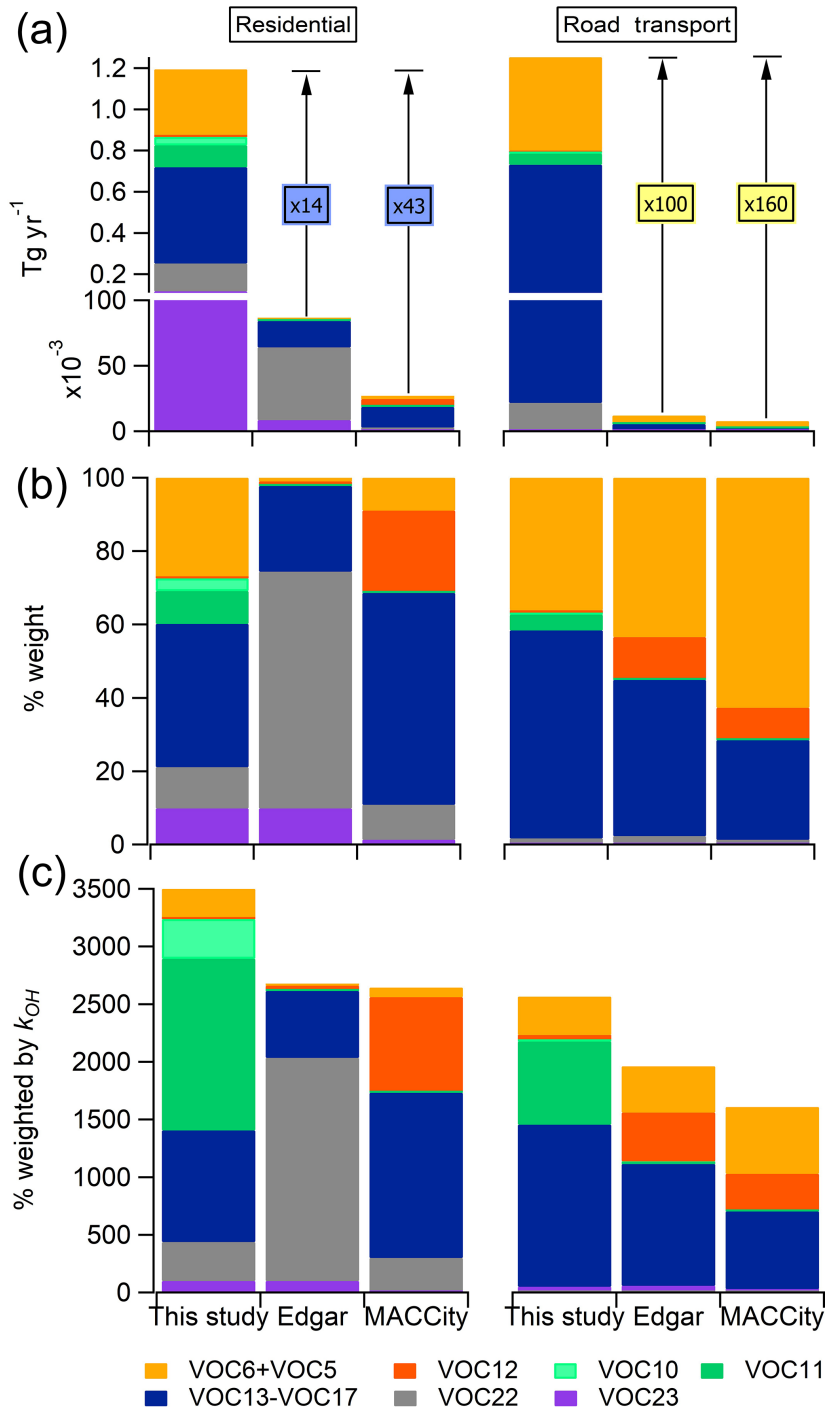

Figure 8. Comparison of VOC emission profiles for Côte d'Ivoire from the emissions estimated from the measurements of this study and the EDGAR v4.3.2 (Huang et al., 2017) and MACCity inventories (Granier et al., 2011). The profile analysis integrates road transportation and residential sectors based on the sector activity for 2012. (a) Absolute emissions, in $\mathrm{Tg} \mathrm{yr}^{-1}$, (b) relative mass contribution, and (c) relative mass reactivity, considering $100 \mathrm{Tg}$ of emissions weighted by the $k_{\mathrm{OH}}$ reaction rate calculated for each VOC family.

VOC12 (alkene) contribution observed in the residential sector, presenting greater emissions in the global inventories. The comparison between both inventories also depicted considerable discrepancies of a factor of 3 .

A similar profile is observed for heavier alkanes (VOC6) which present an analogous contribution between our estimation and EDGAR emissions (34\% and 37\%, respectively; Fig. 8b). Nevertheless, the alkane (VOC5 + VOC6) contribution in the MACCity profiles prevails over road transport emissions, accounting for $62 \%$ of the total emissions.
Interestingly, terpenes and isoprene emissions can be denoted in both sectors in the Côte d'Ivoire calculated emissions (VOC11 and VOC10). Despite the reduced contribution of these species $(9 \%$ in residential and $4 \%$ in road transport), the underestimation of them in the emissions from anthropogenic sources could have consequences for atmospheric chemistry. Since the reactivity is specific for each VOC, the inaccuracies in the speciation could also have implications for the estimation of their impacts. Specifically for terpenes (VOC11), their high contribution in the $k_{\mathrm{OH}}$ reactivity can be noted, accounting for $42 \%$ in the residential sector and $28 \%$ in road transport sector reactivities (Fig. 8c). Even though the total $\mathrm{OH}$ reactivity in all profiles is rather similar, the alkene fraction in this study is not well-represented, which could increase the contribution in terms of reactivity.

Figure 9 also displays the residential and road transportation profiles obtained from Côte d'Ivoire, compared with EDGAR v4.3.2 profiles for Europe. Noticeably in our estimations, road transport and residential sectors presented comparable total emissions, whereas those from the EDGAR inventory were different by a factor of 8 (86.1 versus $12.1 \mathrm{Gg} \mathrm{yr}^{-1}$, respectively). Similar disagreements are also observed when comparing EDGAR total emissions for Europe with Côte d'Ivoire, where the former presents larger emissions (198 versus 86 and 433 versus $12 \mathrm{Gg} \mathrm{yr}^{-1}$, respectively). We highlight here the substantial differences in total emissions, outpacing those estimated for Europe by a factor of 3 for road transport and by a factor of 6 for the residential sector (433 and $198 \mathrm{Gg} \mathrm{yr}^{-1}$, respectively).

The lack of measurements and source profile data in Africa was previously pointed out in the development of the EDGAR inventory, which led to considering the priority of this region for future inventory improvements (Huang et al., 2017). Even though our VOC database is not extensive for all the species emitted by the sources analysed, the incorporation of new VOC species reinforces the usefulness of in situ measurements under real conditions to derive realistic emission factors and subsequent estimates of representative emission profiles.

\subsection{Anthropogenic emissions of terpenes, IVOCs, and aldehydes in southern West Africa}

As previously highlighted, terpenes commonly emitted by biogenic sources were observed in the emissions from anthropogenic sources. Global emission inventories wholly neglect these emissions; however, they could have considerable effects on the atmospheric chemical processing by producing secondary pollutants in the atmosphere. Figure 10a shows the fractional distribution of terpenes in several analysed emission sources. The main contributions are associated with the emissions from waste burning (47\%), twowheel vehicle $(20 \%)$, wood fuel burning $(17 \%)$ and charcoal making $(14 \%)$ sources. The total annual emissions estimated for these compounds, which represent $334 \mathrm{Gg} \mathrm{yr}^{-1}$ 

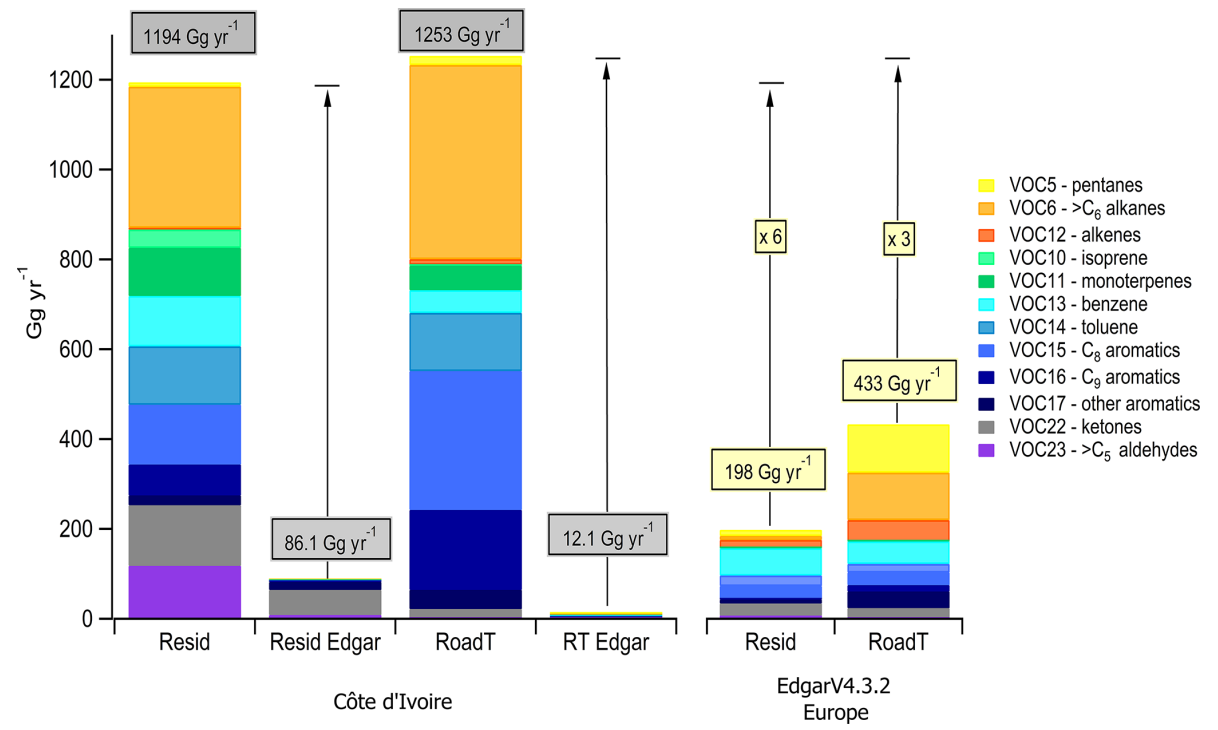

Figure 9. VOC emission profiles considering all the VOC families calculated from the measurements of our study and compared with the global EDGAR v4.3.2 inventory (Huang et al., 2017). The comparison integrates road transportation (RT) and residential (Resid) sectors in Côte d'Ivoire and Europe for the year 2012. Absolute emissions are expressed in $\mathrm{Gg} \mathrm{yr}^{-1}$ for each VOC group.

(a)

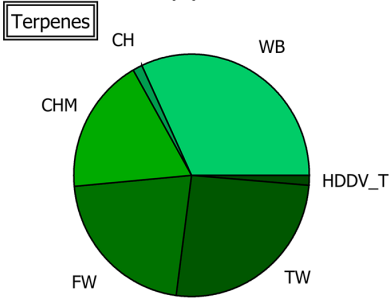

$\underline{\text { Total emissions }=334 \mathrm{Gg} \mathrm{yr}^{-1}}$ (b)

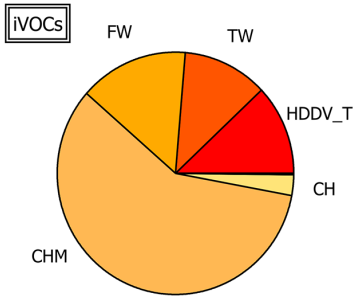

Total emissions $=80 \mathrm{Gg} \mathrm{yr}^{-1}$

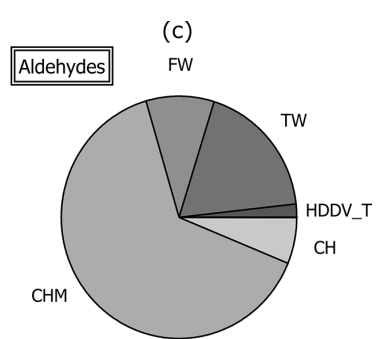

$\underline{\text { Total emissions* }=170 \mathrm{Gg} \mathrm{yr}^{-1}}$

Figure 10. Total estimated emissions and relative distributions in the anthropogenic sources measured in Côte d'Ivoire for the VOC family. (a) Terpenes. (b) IVOCs. (c) Aldehydes (* for aldehyde species $>\mathrm{C}_{6}$ ).

and $11 \%$ of the total emissions, cannot be neglected when compared with the emission of other well-known anthropogenic VOCs, i.e. $\mathrm{C}_{9}$ aromatics. Evaluating the distribution of terpene species among the emission sources permits a different pattern to be noted (Fig. 11). While terpene emissions from road transport are mainly dominated by $\alpha$-ocimene and $\alpha$-terpinolene, limonene and isoprene are mainly emitted by wood-burning sources. The main wood types burned in Côte d'Ivoire are Hevea (Hevea brasiliensis) and Iroko (Milicia excelsa), which are widely used in urban domestic fires for cooking, heating, and other services (Keita et al., 2018). In our study, we only present the results obtained from Hevea, a tropical African hardwood, characterized as a species that emits monoterpenes (Bracho-Nunez et al., 2013; Wang et al., 2007). The principal monoterpene compounds naturally emitted by Hevea species are sabinene, limonene, and $\alpha$-pinene (Bracho-Nunez et al., 2013). The isoprene emissions from non-isoprene emitting species were already observed in biomass burning studies, which indicates that iso- prene is formed during the combustion process (Hatch et al., 2015).

As can be noted in Fig. 11, isoprene emissions are also impacted by vehicles, mainly two-wheel sources, and camphene and $\beta$-pinene emissions by heavy-duty vehicle sources. The anthropogenic sources of isoprene have been documented in urban areas, mainly associated with traffic emissions (Borbon et al., 2001; von Schneidemesser et al., 2011). However, to the best of our knowledge, no previous studies have ever analysed the presence of monoterpenes from road transportation sources. $\alpha$-pinene and $\beta$-pinene emissions are dominated by charcoal burning fires, which also contribute in some fraction to the emissions of isoprene and limonene. In contrast, charcoal making emissions are dominated by $\gamma$-terpinene and isoprene. The results from biomass burning sources provided here were obtained from non-controlled experiments, which did not allow the evaluation of differences between the emissions from each combustion phase (pyrolysis, flaming, and smouldering). Further 


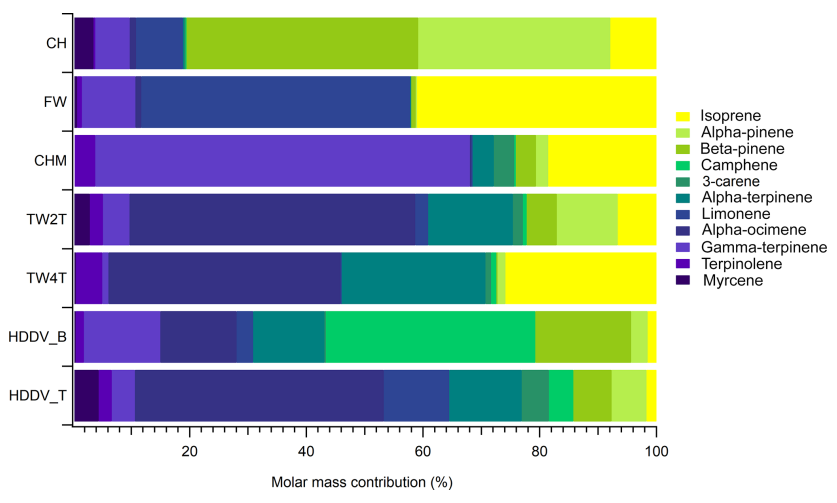

Figure 11. Distribution of monoterpenes and isoprene in the emission sources measured in Abidjan. The values represent the percentage of each terpenoid over the total emission estimated for these species.

investigation is needed in order to develop a better understanding of these differences and to characterize the different combustion phases.

VOCs of intermediate volatility are suspected to be efficient precursors of SOA (Seinfeld and Pandis, 2006, and references therein). However, as was discussed in Sect. 3.4.3, our method was not able to resolve the differences between VOC families, and most SOAP was assigned to aromatic compounds (up to $98 \%$ ). Figure $10 \mathrm{~b}$ reports the fractional contribution and total emissions of IVOCs. Charcoal making, wood fuel burning, heavy-duty diesel vehicles, and twowheel vehicles represent the primary sources of these compounds, accounting for $58 \%, 15 \%, 12 \%$, and $11 \%$ of the total, respectively. Despite their lower emissions compared with aromatics or terpenes, IVOCs are estimated to account for $80 \mathrm{Gg} \mathrm{yr}^{-1}$ of emissions in Côte d'Ivoire. A recent study observed that fine particles in Abidjan are 3 times higher than the World Health Organization recommended concentrations (Djossou et al., 2018). Hence, a better understanding of the aerosol precursors and formation processes is essential for the later reduction of their concentrations in the urban atmosphere.

Oxygenated compounds were previously indicated as essential species in the emissions from burning sources (Gilman et al., 2015; Hatch et al., 2015; Koss et al., 2018; Wiedinmyer et al., 2014). In addition, oxygenated compounds like non-aromatics were dominant in the burning emission sources, including a range of functional groups, of which alcohols and carbonyls were the most abundant (Koss et al., 2018; Stockwell et al., 2015). Figure 10c shows that aldehyde emissions are mainly governed by charcoal making, two-wheel vehicle, and wood burning sources (Fig. 10c). In our study the quantified aldehydes represent only $5.5 \%$ of the total emissions of the country $\left(170 \mathrm{Gg} \mathrm{yr}^{-1}\right)$. However, they can be essential compounds concerning reactivity and ozone formation. Hence, further analysis of oxygenated com- pounds together with furans and other nitro-oxygenated compounds needs to be addressed in future campaigns, in order not only to improve the quantification of these compounds, but also to provide a better identification of the African tracers from biomass burning processes.

\section{Summary and conclusions}

This study reports for the first time a chemically detailed range of VOCs, including $\mathrm{C}_{5}-\mathrm{C}_{16}$ alkanes, monoterpenes, alkenes, aromatics, and carbonyl compounds by using sorbent tubes during an intensive field campaign in Abidjan, southern West Africa. We present here an original dataset integrating main emission sources and ambient measurements from nine representative sites and covering the urban spatial distribution of VOCs in Abidjan. The spatial distribution and composition of VOC in ambient air in Abidjan reveals the effect of local burning and traffic emissions. The highest concentrations were observed near domestic fires, landfill waste fires, and traffic sites, in agreement with the results reported in previous studies, when gas-phase and aerosol pollutants were measured.

The calculation of emission ratios is an important metric to evaluate the estimates provided by global emission inventories. Emission ratios from region-specific emission sources were established here and later used for the analysis of fractional molar mass contribution and the estimation of potential $\mathrm{VOC} \mathrm{OH}$ reactivity, ozone, and secondary organic aerosol formation. The distribution of VOC emissions (magnitude and composition) was different for each evaluated source. Two-wheel and heavy-duty vehicle sources presented the most significant total molar mass emissions, while charcoal burning was the lowest. The sources related to burning processes, such as waste and wood burning, also presented significant contribution to VOC emissions. These sources represent common activities present in Abidjan and might contribute a large quantity of VOC emissions to the southern West African region.

Regarding VOC speciation, molar mass contributions were mostly dominated by aromatic and alkane compounds. Since few alkene species were quantified, aromatics ruled both ozone and SOA formation potential. However, the SOA metrics applied here were not able to accurately analyse the other important SOA precursors' contribution, such as monoterpenes. Nevertheless, monoterpenes can contribute significantly to $\mathrm{VOC} \mathrm{OH}$ reactivity from some sources like waste burning, and the alkane species can significantly contribute to the total reactivity.

In order to estimate the magnitude of VOC emissions in Côte d'Ivoire, emission factors were determined from the in situ VOC database. Road transportation and residential profiles were obtained and compared with those reported in global emission inventories (MACCity and EDGAR). Our results revealed a discrepancy of up to factors of 43 and 160 
for residential and transport profiles when compared with both referenced inventories. The high levels of VOC emissions obtained for Côte d'Ivoire outpace European emissions by up to a factor of 6 . Interestingly, monoterpene emissions were observed in anthropogenic emission sources from biomass burning to road transportation sources, contributing up to $340 \mathrm{Gg} \mathrm{yr}^{-1}$. These compounds are generally missing in the global anthropogenic emission profiles, which would underestimate their impacts on air quality. This underestimation is expected not only for Côte d'Ivoire, but also for all West African countries.

This study, in the framework of the DACCIWA project, allowed us for the first time to identify and quantify several VOCs in ambient air and at emission sources in Abidjan, Côte d'Ivoire. Our results provide significant constraints for the development of more realistic regional emission inventories. A continuous effort is needed to collect new emission data and ambient measurements in West African countries for all critical atmospheric pollutants.

Data availability. All data used in this study are available at the AERIS Data and Service Center, which can be found at http: //baobab.sedoo.fr/DACCIWA, last access: 18 July 2019).

Supplement. The supplement related to this article is available online at: https://doi.org/10.5194/acp-19-11721-2019-supplement.

Author contributions. PD conducted the analysis of the data and, together with $\mathrm{AB}$, wrote the paper. SK, JB, VY, and CGL performed the measurement during the different field campaigns. PD, AC, LB, SS, and AB performed the GC-FID and GC-MS analysis and provided the final VOC data used in this paper. CL led the workpackage activities and, together with AB, coordinated the DACCIWA VOC field campaign. EM improved the quality of the paper and provided English support in the writing process. All co-authors contributed to the discussion of the results and the writing of the paper.

Competing interests. The authors declare that they have no conflict of interest.

Special issue statement. This article is part of the special issue "Results of the project "Dynamics-aerosol-chemistry-cloud interactions in West Africa" (DACCIWA) (ACP/AMT inter-journal SI)". It is not associated with a conference.

Acknowledgements. This work has received funding from the European Union Seventh Framework Programme (FP7/2007-2013) under grant agreement number 603502 (EU project DACCIWA: Dynamics-aerosol-chemistry-cloud interactions in West Africa). Pamela Dominutti acknowledges the Postdoctoral Fellowship support from the Université Clermont Auvergne and is thankful for the grant received from the CAPES programme (process no.: 88887.098995/2015-00, CAPES - PVE's Program, 2014) from the Ministry of Education of Brazil during 2015-2016. Thierry Leonardis is thanked for the contribution to the analysis of VOC sorbent tubes, graciously performed at the SAGE Department at IMT Lille Douai (France).

Financial support. This research has been supported by the European Commission (DACCIWA (grant no. 603502)).

Review statement. This paper was edited by Mathew Evans and reviewed by two anonymous referees.

\section{References}

AIRPARIF: Surveillance de la qualite de l'air en Ile-deFrance, available at: http://www.airparif.asso.fr/ (last access: 1 March 2018), 2016.

Ait-Helal, W., Borbon, A., Sauvage, S., de Gouw, J. A., Colomb, A., Gros, V., Freutel, F., Crippa, M., Afif, C., Baltensperger, U., Beekmann, M., Doussin, J.-F., Durand-Jolibois, R., Fronval, I., Grand, N., Leonardis, T., Lopez, M., Michoud, V., Miet, K., Perrier, S., Prévôt, A. S. H., Schneider, J., Siour, G., Zapf, P., and Locoge, N.: Volatile and intermediate volatility organic compounds in suburban Paris: variability, origin and importance for SOA formation, Atmos. Chem. Phys., 14, 10439-10464, https://doi.org/10.5194/acp-14-10439-2014, 2014.

Akagi, S. K., Yokelson, R. J., Wiedinmyer, C., Alvarado, M. J., Reid, J. S., Karl, T., Crounse, J. D., and Wennberg, P. O.: Emission factors for open and domestic biomass burning for use in atmospheric models, Atmos. Chem. Phys., 11, 4039-4072, https://doi.org/10.5194/acp-11-4039-2011, 2011.

Assamoi, E.-M. and Liousse, C.: A new inventory for two-wheel vehicle emissions in West Africa for 2002, Atmos. Environ., 44, 3985-3996, https://doi.org/10.1016/j.atmosenv.2010.06.048, 2010.

Atkinson, R. and Arey, J.: Atmospheric Degradation of Volatile Organic Compounds, Chem. Rev., 103, 4605-4638, https://doi.org/10.1021/cr0206420, 2003.

Bahino, J., Yoboué, V., Galy-Lacaux, C., Adon, M., Akpo, A., Keita, S., Liousse, C., Gardrat, E., Chiron, C., Ossohou, M., Gnamien, S., and Djossou, J.: A pilot study of gaseous pollutants' measurement $\left(\mathrm{NO}_{2}, \mathrm{SO}_{2}, \mathrm{NH}_{3}, \mathrm{HNO}_{3}\right.$ and $\left.\mathrm{O}_{3}\right)$ in Abidjan, Côte d'Ivoire: contribution to an overview of gaseous pollution in African cities, Atmos. Chem. Phys., 18, 5173-5198, https://doi.org/10.5194/acp-18-5173-2018, 2018.

Baker, A. K., Beyersdorf, A. J., Doezema, L. A., Katzenstein, A., Meinardi, S., Simpson, I. J., Blake, D. R., and Sherwood, F. R.: Measurements of nonmethane hydrocarbons in 28 United States cities, Atmos. Environ., 42, 170-182, https://doi.org/10.1016/j.atmosenv.2007.09.007, 2008.

Barletta, B., Meinardi, S., Simpson, I. J., Khwaja, H. A., Blake, D. R., and Rowland, F. S.: Mixing ratios of volatile organic compounds (VOCs) in the atmosphere of Karachi, Pakistan, Atmos. Environ., 36, 3429-3443, https://doi.org/10.1016/S13522310(02)00302-3, 2002. 
Bechara, J., Borbon, A., Jambert, C., Colomb, A., and Perros, P. E.: Evidence of the impact of deep convection on reactive Volatile Organic Compounds in the upper tropical troposphere during the AMMA experiment in West Africa, Atmos. Chem. Phys., 10, 10321-10334, https://doi.org/10.5194/acp-10-103212010, 2010.

Bon, D. M., Ulbrich, I. M., de Gouw, J. A., Warneke, C., Kuster, W. C., Alexander, M. L., Baker, A., Beyersdorf, A. J., Blake, D., Fall, R., Jimenez, J. L., Herndon, S. C., Huey, L. G., Knighton, W. B., Ortega, J., Springston, S., and Vargas, O.: Measurements of volatile organic compounds at a suburban ground site (T1) in Mexico City during the MILAGRO 2006 campaign: measurement comparison, emission ratios, and source attribution, Atmos. Chem. Phys., 11, 2399-2421, https://doi.org/10.5194/acp11-2399-2011, 2011.

Borbon, A., Fontaine, H., Veillerot, M., Locoge, N., Galloo, J. C., and Guillermo, R.: An investigation into the traffic-related fraction of isoprene at an urban location, Atmos. Environ., 35, 37493760, https://doi.org/10.1016/S1352-2310(01)00170-4, 2001.

Borbon, A., Locoge, N., Veillerot, M., Galloo, J. C., and Guillermo, R.: Characterisation of NMHCs in a French urban atmosphere: overview of the main sources, Sci. Total Environ., 292, 177-191, https://doi.org/10.1016/S0048-9697(01)01106-8, 2002.

Borbon, A., Gilman, J. B., Kuster, W. C., Grand, N., Chevaillier, S., Colomb, A., Dolgorouky, C., Gros, V., Lopez, M., Sarda-Esteve, R., Holloway, J., Stutz, J., Petetin, H., McKeen, S., Beekmann, M., Warneke, C., Parrish, D. D., and de Gouw, J. A.: Emission ratios of anthropogenic volatile organic compounds in northern mid-latitude megacities: Observations versus emission inventories in Los Angeles and Paris, J. Geophys. Res.-Atmos., 118, 2041-2057, https://doi.org/10.1002/jgrd.50059, 2013.

Borbon, A., Boynard, A., Salameh, T., Baudic, A., Gros, V., Gauduin, J., Perrussel, O., and Pallares, C.: Is Traffic Still an Important Emitter of Monoaromatic Organic Compounds in European Urban Areas?, Environ. Sci. Technol., 52, 513-521, https://doi.org/10.1021/acs.est.7b01408, 2018.

Boynard, A., Borbon, A., Leonardis, T., Barletta, B., Meinardi, S., Blake, D. R., and Locoge, N.: Spatial and seasonal variability of measured anthropogenic non-methane hydrocarbons in urban atmospheres: Implication on emission ratios, Atmos. Environ., 82, 258-267, https://doi.org/10.1016/j.atmosenv.2013.09.039, 2014.

Bracho-Nunez, A., Knothe, N. M., Welter, S., Staudt, M., Costa, W. R., Liberato, M. A. R., Piedade, M. T. F., and Kesselmeier, J.: Leaf level emissions of volatile organic compounds (VOC) from some Amazonian and Mediterranean plants, Biogeosciences, 10, 5855-5873, https://doi.org/10.5194/bg-10-5855-2013, 2013.

Brito, J., Wurm, F., Yáñez-Serrano, A. M., de Assunção, J. V., Godoy, J. M., and Artaxo, P.: Vehicular Emission Ratios of VOCs in a Megacity Impacted by Extensive Ethanol Use: Results of Ambient Measurements in São Paulo, Brazil, Environ. Sci. Technol., 49, 11381-11387, https://doi.org/10.1021/acs.est.5b03281, 2015.

Brocco, D., Fratarcangeli, R., Lepore, L., Petricca, M., and Ventrone, I.: Determination of aromatic hydrocarbons in urban air of Rome, Atmos. Environ., 31, 557-566, https://doi.org/10.1016/S1352-2310(96)00226-9, 1997.

de Gouw, J. A., Gilman, J. B., Kim, S.-W., Lerner, B. M., IsaacmanVanWertz, G., McDonald, B. C., Warneke, C., Kuster, W. C., Lefer, B. L., Griffith, S. M., Dusanter, S., Stevens, P. S., and
Stutz, J.: Chemistry of Volatile Organic Compounds in the Los Angeles basin: Nighttime Removal of Alkenes and Determination of Emission Ratios, J. Geophys. Res.-Atmos., 122, 1184311861, https://doi.org/10.1002/2017JD027459, 2017.

Deroubaix, A., Menut, L., Flamant, C., Brito, J., Denjean, C., Dreiling, V., Fink, A., Jambert, C., Kalthoff, N., Knippertz, P., Ladkin, R., Mailler, S., Maranan, M., Pacifico, F., Piguet, B., Siour, G., and Turquety, S.: Diurnal cycle of coastal anthropogenic pollutant transport over southern West Africa during the DACCIWA campaign, Atmos. Chem. Phys., 19, 473-497, https://doi.org/10.5194/acp-19-473-2019, 2019.

Derwent, R. G., Jenkin, M. E., Saunders, S. M., and Pilling, M. J.: Photochemical ozone creation potentials for organic compounds in northwest Europe calculated with a master chemical mechanism, Atmos. Environ., 32, 2429-2441, https://doi.org/10.1016/S1352-2310(98)00053-3, 1998.

Derwent, R. G., Jenkin, M. E., Passant, N. R., and Pilling, M. J.: Photochemical ozone creation potentials (POCPs) for different emission sources of organic compounds, Atmos. Environ., 41, 2570-2579, https://doi.org/10.1016/j.atmosenv.2006.11.019, 2007.

Derwent, R. G., Jenkin, M. E., Utembe, S. R., Shallcross, D. E., Murrells, T. P., and Passant, N. R.: Secondary organic aerosol formation from a large number of reactive manmade organic compounds, Sci. Total Environ., 408, 3374-3381, https://doi.org/10.1016/j.scitotenv.2010.04.013, 2010.

Detournay, A., Sauvage, S., Locoge, N., Gaudion, V., Leonardis, T., Fronval, I., Kaluzny, P., and Galloo, J.-C.: Development of a sampling method for the simultaneous monitoring of straightchain alkanes, straight-chain saturated carbonyl compounds and monoterpenes in remote areas, J. Environ. Monit., 13, 983-90, https://doi.org/10.1039/c0em00354a, 2011.

Djossou, J., Léon, J.-F., Akpo, A. B., Liousse, C., Yoboué, V., Bedou, M., Bodjrenou, M., Chiron, C., Galy-Lacaux, C., Gardrat, E., Abbey, M., Keita, S., Bahino, J., Touré N'Datchoh, E., Ossohou, M., and Awanou, C. N.: Mass concentration, optical depth and carbon composition of particulate matter in the major southern West African cities of Cotonou (Benin) and Abidjan (Côte d'Ivoire), Atmos. Chem. Phys., 18, 6275-6291, https://doi.org/10.5194/acp-18-6275-2018, 2018.

Dominutti, P. A., Nogueira, T., Borbon, A., Andrade, M. de F., and Fornaro, A.: One-year of NMHCs hourly observations in São Paulo megacity: meteorological and traffic emissions effects in a large ethanol burning context, Atmos. Environ., 142, 371-382, https://doi.org/10.1016/j.atmosenv.2016.08.008, 2016.

Epstein, S. A., Riipinen, I., and Donahue, N. M.: A Semiempirical Correlation between Enthalpy of Vaporization and Saturation Concentration for Organic Aerosol, Environ. Sci. Technol., 44, 743-748, https://doi.org/10.1021/es902497z, 2010.

Gaimoz, C., Sauvage, S., Gros, V., Herrmann, F., Williams, J., Locoge, N., Perrussel, O., Bonsang, B., D’Argouges, O., Sarda-Estève, R., and Sciare, J.: Volatile organic compounds sources in Paris in spring 2007. Part II: source apportionment using positive matrix factorisation, Environ. Chem., 8, 91, https://doi.org/10.1071/EN10067, 2011.

Gilman, J. B., Lerner, B. M., Kuster, W. C., Goldan, P. D., Warneke, C., Veres, P. R., Roberts, J. M., de Gouw, J. A., Burling, I. R., and Yokelson, R. J.: Biomass burning emissions and potential air quality impacts of volatile organic compounds and 
other trace gases from fuels common in the US, Atmos. Chem. Phys., 15, 13915-13938, https://doi.org/10.5194/acp-15-139152015, 2015.

Granier, C., Bessagnet, B., Bond, T., D’Angiola, A., Denier van der Gon, H., Frost, G. J., Heil, A., Kaiser, J. W., Kinne, S., Klimont, Z., Kloster, S., Lamarque, J.-F., Liousse, C., Masui, T., Meleux, F., Mieville, A., Ohara, T., Raut, J.-C., Riahi, K., Schultz, M. G., Smith, S. J., Thompson, A., van Aardenne, J., van der Werf, G. R., and van Vuuren, D. P.: Evolution of anthropogenic and biomass burning emissions of air pollutants at global and regional scales during the 1980-2010 period, Clim. Change, 109, 163-190, https://doi.org/10.1007/s10584-011-0154-1, 2011.

Hatch, L. E., Luo, W., Pankow, J. F., Yokelson, R. J., Stockwell, C. E., and Barsanti, K. C.: Identification and quantification of gaseous organic compounds emitted from biomass burning using two-dimensional gas chromatography-time-offlight mass spectrometry, Atmos. Chem. Phys., 15, 1865-1899, https://doi.org/10.5194/acp-15-1865-2015, 2015.

Heeb, N. V., Forss, A.-M., Bach, C., Reimann, S., Herzog, A., and Jäckle, H. W.: A comparison of benzene, toluene and C2benzenes mixing ratios in automotive exhaust and in the suburban atmosphere during the introduction of catalytic converter technology to the Swiss Car Fleet, Atmos. Environ., 34, 31033116, https://doi.org/10.1016/S1352-2310(99)00446-X, 2000.

Huang, G., Brook, R., Crippa, M., Janssens-Maenhout, G., Schieberle, C., Dore, C., Guizzardi, D., Muntean, M., Schaaf, E., and Friedrich, R.: Speciation of anthropogenic emissions of non-methane volatile organic compounds: a global gridded data set for 1970-2012, Atmos. Chem. Phys., 17, 7683-7701, https://doi.org/10.5194/acp-17-7683-2017, 2017.

Jaars, K., Beukes, J. P., van Zyl, P. G., Venter, A. D., Josipovic, M., Pienaar, J. J., Vakkari, V., Aaltonen, H., Laakso, H., Kulmala, M., Tiitta, P., Guenther, A., Hellén, H., Laakso, L., and Hakola, H.: Ambient aromatic hydrocarbon measurements at Welgegund, South Africa, Atmos. Chem. Phys., 14, 7075-7089, https://doi.org/10.5194/acp-14-7075-2014, 2014.

Jaars, K., van Zyl, P. G., Beukes, J. P., Hellén, H., Vakkari, V., Josipovic, M., Venter, A. D., Räsänen, M., Knoetze, L., Cilliers, D. P., Siebert, S. J., Kulmala, M., Rinne, J., Guenther, A., Laakso, L., and Hakola, H.: Measurements of biogenic volatile organic compounds at a grazed savannah grassland agricultural landscape in South Africa, Atmos. Chem. Phys., 16, 15665-15688, https://doi.org/10.5194/acp-16-15665-2016, 2016.

Jenkin, M. E., Derwent, R. G., and Wallington, T. J.: Photochemical ozone creation potentials for volatile organic compounds: Rationalization and estimation, Atmos. Environ., 163, 128-137, https://doi.org/10.1016/j.atmosenv.2017.05.024, 2017.

Keita, S., Liousse, C., Yoboué, V., Dominutti, P., Guinot, B., Assamoi, E.-M., Borbon, A., Haslett, S. L., Bouvier, L., Colomb, A., Coe, H., Akpo, A., Adon, J., Bahino, J., Doumbia, M., Djossou, J., Galy-Lacaux, C., Gardrat, E., Gnamien, S., Léon, J. F., Ossohou, M., N'Datchoh, E. T., and Roblou, L.: Particle and VOC emission factor measurements for anthropogenic sources in West Africa, Atmos. Chem. Phys., 18, 7691-7708, https://doi.org/10.5194/acp-18-7691-2018, 2018.

Knippertz, P., Coe, H., Chiu, J. C., Evans, M. J., Fink, A. H., Kalthoff, N., Liousse, C., Mari, C., Allan, R. P., Brooks, B., Danour, S., Flamant, C., Jegede, O. O., Lohou, F., and Marsham, J. H.: The DACCIWA Project: Dynamics-Aerosol-
Chemistry-Cloud Interactions in West Africa, B. Am. Meteorol. Soc., 96, 1451-1460, https://doi.org/10.1175/BAMS-D-1400108.1, 2015a.

Knippertz, P., Evans, M. J., Field, P. R., Fink, A. H., Liousse, C., and Marsham, J. H.: The possible role of local air pollution in climate change in West Africa, Nat. Clim. Chang., 5, 815-822, https://doi.org/10.1038/nclimate2727, 2015b.

Knippertz, P., Fink, A. H., Deroubaix, A., Morris, E., Tocquer, F., Evans, M. J., Flamant, C., Gaetani, M., Lavaysse, C., Mari, C., Marsham, J. H., Meynadier, R., Affo-Dogo, A., Bahaga, T., Brosse, F., Deetz, K., Guebsi, R., Latifou, I., Maranan, M., Rosenberg, P. D., and Schlueter, A.: A meteorological and chemical overview of the DACCIWA field campaign in West Africa in June-July 2016, Atmos. Chem. Phys., 17, 10893-10918, https://doi.org/10.5194/acp-17-10893-2017, 2017.

Koss, A. R., Sekimoto, K., Gilman, J. B., Selimovic, V., Coggon, M. M., Zarzana, K. J., Yuan, B., Lerner, B. M., Brown, S. S., Jimenez, J. L., Krechmer, J., Roberts, J. M., Warneke, C., Yokelson, R. J., and de Gouw, J.: Non-methane organic gas emissions from biomass burning: identification, quantification, and emission factors from PTR-ToF during the FIREX 2016 laboratory experiment, Atmos. Chem. Phys., 18, 3299-3319, https://doi.org/10.5194/acp-18-3299-2018, 2018.

Kumar, A., Singh, D., Kumar, K., Singh, B. B., and Jain, V. K.: Distribution of VOCs in urban and rural atmospheres of subtropical India: Temporal variation, source attribution, ratios, OFP and risk assessment, Sci. Total Environ., 613-614, 492-501, https://doi.org/10.1016/j.scitotenv.2017.09.096, 2018.

Liousse, C., Assamoi, E., Criqui, P., Granier, C., and Rosset, R.: Explosive growth in African combustion emissions from 2005 to 2030, Environ. Res. Lett., 9, 035003, https://doi.org/10.1088/1748-9326/9/3/035003, 2014.

Manion, J. A., Huie, R. E., Levin Jr., R. D., D. R. B., Orkin, V. L., Tsang, W., McGivern, W. S., Hudgens, J. W., Knyazev, V. D., Atkinson, D. B., Chai, E., Tereza, A. M., Lin, C.-Y., Allison, T. C., Mallard, W. G., Westley, F., Herron, J. T., Hampson, A., and Frizzell, D. H.: NIST Chemical Kinetics Database, Gaithersburg, Maryland, available at: http://kinetics.nist.gov/ (last access: 18 April 2018), 2015.

Mari, C. H., Reeves, C. E., Law, K. S., Ancellet, G., AndrésHernández, M. D., Barret, B., Bechara, J., Borbon, A., Bouarar, I., Cairo, F., Commane, R., Delon, C., Evans, M. J., Fierli, F., Floquet, C., Galy-Lacaux, C., Heard, D. E., Homan, C. D., Ingham, T., Larsen, N., Lewis, A. C., Liousse, C., Murphy, J. G., Orlandi, E., Oram, D. E., Saunois, M., Serça, D., Stewart, D. J., Stone, D., Thouret, V., van Velthoven, P., and Williams, J. E.: Atmospheric composition of West Africa: Highlights from the AMMA international program, Atmos. Sci. Lett., 12, 13-18, https://doi.org/10.1002/asl.289, 2011.

Muezzinoglu, A., Odabasi, M., and Onat, L.: Volatile organic compounds in the air of Izmir, Turkey, Atmos. Environ., 35, 753-760, https://doi.org/10.1016/S1352-2310(00)00420-9, 2001.

Niedojadlo, A., Becker, K. H., Kurtenbach, R., and Wiesen, P.: The contribution of traffic and solvent use to the total NMVOC emission in a German city derived from measurements and CMB modelling, Atmos. Environ., 41, 7108-7126, https://doi.org/10.1016/j.atmosenv.2007.04.056, 2007. 
OpenStreetMap contributors: Maps of Abidjan area, available at: https://www.openstreetmap.org (last access: 20 August 2019), 2015.

Robinson, A. L., Donahue, N. M., Shrivastava, M. K., Weitkamp, E. A., Sage, A. M., Grieshop, A. P., Lane, T. E., Pierce, J. R., and Pandis, S. N.: Rethinking Organic Aerosols: Semivolatile Emissions and Photochemical Aging, Science, 315, 1259-1262, https://doi.org/10.1126/science.1133061, 2007.

Salameh, T., Afif, C., Sauvage, S., Borbon, A., and Locoge, N.: Speciation of non-methane hydrocarbons (NMHCs) from anthropogenic sources in Beirut, Lebanon, Environ. Sci. Pollut. Res., 21, 10867-10877, https://doi.org/10.1007/s11356-0142978-5, 2014.

Salameh, T., Sauvage, S., Afif, C., Borbon, A., Leónardis, T., Brioude, J., Waked, A., and Locoge, N.: Exploring the seasonal NMHC distribution in an urban area of the Middle East during ECOCEM campaigns: Very high loadings dominated by local emissions and dynamics, Environ. Chem., 12, 316-328, https://doi.org/10.1071/EN14154, 2015.

Salameh, T., Borbon, A., Afif, C., Sauvage, S., Leonardis, T., Gaimoz, C., and Locoge, N.: Composition of gaseous organic carbon during ECOCEM in Beirut, Lebanon: new observational constraints for VOC anthropogenic emission evaluation in the Middle East, Atmos. Chem. Phys., 17, 193-209, https://doi.org/10.5194/acp-17-193-2017, 2017a.

Salameh, T., Sauvage, S., Afif, C., Borbon, A., and Locoge, N.: Source apportionment vs. emission inventories of non-methane hydrocarbons (NMHC) in an urban area of the Middle East: local and global perspectives, Atmos. Chem. Phys., 16, 3595-3607, https://doi.org/10.5194/acp-16-3595-2016, 2016b.

Saxton, J. E., Lewis, A. C., Kettlewell, J. H., Ozel, M. Z., Gogus, F., Boni, Y., Korogone, S. O. U., and Serça, D.: Isoprene and monoterpene measurements in a secondary forest in northern Benin, Atmos. Chem. Phys., 7, 4095-4106, https://doi.org/10.5194/acp-7-4095-2007, 2007.

Seinfeld, J. H. and Pandis, S. N.: Atmospheric Chemistry and Physics. From Air Pollution to Climate Change, Second edn., John Wiley \& Sons, New York, 2006.

Sekimoto, K., Koss, A. R., Gilman, J. B., Selimovic, V., Coggon, M. M., Zarzana, K. J., Yuan, B., Lerner, B. M., Brown, S. S., Warneke, C., Yokelson, R. J., Roberts, J. M., and de Gouw, J.: High- and low-temperature pyrolysis profiles describe volatile organic compound emissions from western US wildfire fuels, Atmos. Chem. Phys., 18, 9263-9281, https://doi.org/10.5194/acp18-9263-2018, 2018.

SIE CI: Rapport Côte d'Ivoire Energie 2010, available at: http://www.ecowrex.org/system/files/repository/2010_rapport_ annuel_sie_-_min_ener.pdf (last access: 27 August 2018), 2010.

Simpson, I. J., Akagi, S. K., Barletta, B., Blake, N. J., Choi, Y., Diskin, G. S., Fried, A., Fuelberg, H. E., Meinardi, S., Rowland, F. S., Vay, S. A., Weinheimer, A. J., Wennberg, P. O., Wiebring, P., Wisthaler, A., Yang, M., Yokelson, R. J., and Blake, D. R.: Boreal forest fire emissions in fresh Canadian smoke plumes: $\mathrm{C}_{1}-\mathrm{C}_{10}$ volatile organic compounds (VOCs), $\mathrm{CO}_{2}, \mathrm{CO}, \mathrm{NO}_{2}$, $\mathrm{NO}, \mathrm{HCN}$ and $\mathrm{CH}_{3} \mathrm{CN}$, Atmos. Chem. Phys., 11, 6445-6463, https://doi.org/10.5194/acp-11-6445-2011, 2011.

Sommariva, R., de Gouw, J. A., Trainer, M., Atlas, E., Goldan, P. D., Kuster, W. C., Warneke, C., and Fehsenfeld, F. C.: Emissions and photochemistry of oxygenated VOCs in urban plumes in the Northeastern United States, Atmos. Chem. Phys., 11, 70817096, https://doi.org/10.5194/acp-11-7081-2011, 2011.

Sommers, W. T., Loehman, R. A., and Hardy, C. C.: Wildland fire emissions, carbon, and climate: Science overview and knowledge needs, For. Ecol. Manage., 317, 1-8, https://doi.org/10.1016/j.foreco.2013.12.014, 2014.

Stockwell, C. E., Veres, P. R., Williams, J., and Yokelson, R. J.: Characterization of biomass burning emissions from cooking fires, peat, crop residue, and other fuels with high-resolution proton-transfer-reaction time-of-flight mass spectrometry, Atmos. Chem. Phys., 15, 845-865, https://doi.org/10.5194/acp-15845-2015, 2015.

United Nations, Department of Economic and Social Affairs, Population Division: World Population Prospects 2017, United Nations, New York (ST/ESA/SER.A/401), 2017.

von Schneidemesser, E., Monks, P. S., and Plass-Duelmer, C.: Global comparison of VOC and $\mathrm{CO}$ observations in urban areas, Atmos. Environ., 44, 5053-5064, https://doi.org/10.1016/j.atmosenv.2010.09.010, 2010.

von Schneidemesser, E., Monks, P. S., Gros, V., Gauduin, J., and Sanchez, O.: How important is biogenic isoprene in an urban environment? A study in London and Paris, Geophys. Res. Lett., 38, L19804, https://doi.org/10.1029/2011GL048647, 2011.

Wang, M., Shao, M., Chen, W., Yuan, B., Lu, S., Zhang, Q., Zeng, L., and Wang, Q.: A temporally and spatially resolved validation of emission inventories by measurements of ambient volatile organic compounds in Beijing, China, Atmos. Chem. Phys., 14, 5871-5891, https://doi.org/10.5194/acp-14-5871-2014, 2014.

Wang, Y.-F., Owen, S. M., Li, Q.-J., and Peñuelas, J.: Monoterpene emissions from rubber trees (Hevea brasiliensis) in a changing landscape and climate: chemical speciation and environmental control, Glob. Change Biol., 13, 2270-2282, https://doi.org/10.1111/j.1365-2486.2007.01441.x, 2007.

Warneke, C., McKeen, S. A., de Gouw, J. A., Goldan, P. D., Kuster, W. C., Holloway, J. S., Williams, E. J., Lerner, B. M., Parrish, D. D., Trainer, M., Fehsenfeld, F. C., Kato, S., Atlas, E. L., Baker, A., and Blake, D. R.: Determination of urban volatile organic compound emission ratios and comparison with an emissions database, J. Geophys. Res., 112, D10S47, https://doi.org/10.1029/2006JD007930, 2007.

Wiedinmyer, C., Yokelson, R. J., and Gullett, B. K.: Global Emissions of Trace Gases, Particulate Matter, and Hazardous Air Pollutants from Open Burning of Domestic Waste, Environ. Sci. Technol., 48, 9523-9530, https://doi.org/10.1021/es502250z, 2014.

Yokelson, R. J., Burling, I. R., Gilman, J. B., Warneke, C., Stockwell, C. E., de Gouw, J., Akagi, S. K., Urbanski, S. P., Veres, P., Roberts, J. M., Kuster, W. C., Reardon, J., Griffith, D. W. T., Johnson, T. J., Hosseini, S., Miller, J. W., Cocker III, D. R., Jung, H., and Weise, D. R.: Coupling field and laboratory measurements to estimate the emission factors of identified and unidentified trace gases for prescribed fires, Atmos. Chem. Phys., 13, 89-116, https://doi.org/10.5194/acp-13-89-2013, 2013.

Zhang, Q., Yuan, B., Shao, M., Wang, X., Lu, S., Lu, K., Wang, M., Chen, L., Chang, C.-C., and Liu, S. C.: Variations of ground-level $\mathrm{O}_{3}$ and its precursors in Beijing in summertime between 2005 and 2011, Atmos. Chem. Phys., 14, 6089-6101, https://doi.org/10.5194/acp-14-6089-2014, 2014. 